\title{
4 The Aeneid: An Epic With A Commentary On Contemporary Affairs
}

In this chapter I consider Vergil's commentary on social and political issues in the Aeneid. My supposition is that the poet's commentary will not only be found in direct or indirect references, but also by Vergil using models, literary and/or functional. Therefore, the chapter is divided into two parts. The first part (section 4.1) is about references, particularly those to Augustus (section 4.1.1), Cleopatra (section 4.1.2) and often to Mark Antony ${ }^{123}$. As it is not possible to discuss the whole Aeneid in a book like this, I will present only a selection of representative examples. The presentation of the results of the analyses of the Aeneid is different from the presentation of the Eclogues. This is because the Aeneid - an unbroken and continuous narrative - cannot be subdivided into distinct individual poems.

The second part (section 4.2) will be concerned with the question whether Vergil used a model for Dido and Aeneas, either a literary or a functional model or both. In particular, I will discuss models in the Aeneid in general (section 4.2.1), the question whether Dido was a historical character and the early myths about her (section 4.2.2), Dido in the Aeneid (section 4.2.3), options of models for Dido (section 4.2.4), and the question whether Cleopatra was a functional model for Dido (section 4.2.5). Finally, I will argue (section 4.2.6) that in some cases Vergil used Augustus as a functional model for Aeneas. At the end of the chapter a short summary will be given in section 4.3 .

In the last chapter 5 I will discuss Vergil's political views bringing together the evidence from the Eclogues, the Georgics and the Aeneid.

\subsection{References In The Aeneid}

I mentioned in section 2.1 that the references found in the Aeneid can be traced in all forms of visual art in the Augustan era. They were understood by the Romans and Galinsky (1996, 141-224) has presented many examples, such as the Ara Pacis, the statue of Augustus of Prima Porta, the portraits of Augustus, wall frescoes, the Forum of Augustus and the temple of Apollo at the Palatine. About the Ara Pacis, which he considers to be the most important monument of the Augustan age, he (Galinsky 1996, 141) says: "In its combination of experimentation, deliberate multiplicity of associations and inspirations, and a clear overall meaning, it is a splendid example of the culture in general"124. In Galinsky's opinion the same holds for poetry and thus

123 In this chapter I will use the name of Augustus that was given to Octavian in 27 B.C..

124 See also the discussions about the Ara Pacis in Kleiner (2005a, 212-225; 2005b, 219-229). 
literature is a continuous interplay of images and associations. (Galinsky, 1996, 225287). In this section I will examine not only the texts where Augustus, Cleopatra, and other leading persons from Vergil's time are mentioned in the Aeneid by name, but also the indirect references to them.

\subsubsection{References To Augustus}

The Aeneid has several direct or quasi-direct references to Augustus. Shortly after a brief reference to the house of the Iulii (A.1.267-268), the first reference to Augustus is found in A.1.286-291, where Venus complains to Iuppiter about the fate of Aeneas caused by the wrath of Iuno. Although in this passage Augustus is not mentioned by name, the words nascetur pulchra Troianus origine Caesar (from this illustrious origin shall be born the Trojan Caesar), in line 286, refer to him: the Iulii claimed to be descendants of Aeneas and, as Iulius Caesar's adoptive son, Augustus had joined this clan. The words which follow a few lines later in A.1.294-296, (claudentur Belli portae; Furor impius intus/saeua sedens super arma (the gates of war shall be closed; within unholy Furor, sitting on savage arms), refer to the end of the civil wars, the coming of peace and the role of Augustus in bringing this about.

Other well-known passages are A.6.789-795 (Augustus will extend the empire beyond the Garamantes (in Africa) and the Indians) and A.8.675-728 (Octavian's fight against Mark Antony and Cleopatra, ending with his great triple triumph). The mention of the coming of the Golden Age, which Anchises foretells in A.6.792-794, Augustus Caesar, diui genus, aurea condet/saecula qui rur sus Latio regnata per arua/Saturno quondam (Caesar Augustus, descendant of a god, who will again found a Golden Age in Latium in the middle of fields once reigned by Saturn) reflects Vergil's high expectations for Augustus' reign. The civil war will end, reconciliation between the warring factions will be achieved and order will be restored ${ }^{125}$. In A.6.794 Augustus is linked to Saturn, the founder of the Roman citadel. The foundation of Rome by Saturn is described in A.8.357: hanc Ianus pater, hanc Saturnus condidit arcem (father Janus built this fort, Saturn the other). Saturn is not only a founder, but also a lawgiver (A.8.319-322: Saturnus [...], legesque dedit (Saturn, and gave them laws), a typical royal prerogative. Linking Augustus to Saturn in the above passage refers to the future kingship of Augustus ${ }^{126}$.

125 The theme of the arrival of the Golden Age and the reconciliation has been discussed comprehensively by Nadeau (2004, 249-267 and 2010a, 226-230).

126 Contrary to Lowrie $(2009,172)$, who does not conclude that the passage refers to future kingship. 
In A.8.626-731, Vergil describes Aeneas' shield. The poet tells us what the shield represents in line 626: res Italas Romanorumque triumphos (the story of Italy and the triumphs of Rome). In lines 671-713, he describes the sea battle near Actium and its immediate aftermath. In this passage the poet shows the contrast between Augustus, who has not only the Senate and the people of Rome, but also the gods at his side, and Mark Antony who is supported by the Egyptian forces and by Cleopatra. The latter is fighting under the threat of imminent death and is aided only by her Egyptian divine evil omens (deum monstra) and not by powerful gods. The role of Cleopatra in the battle of Actium (A.8.671-713) will be discussed in more detail in section 4.1.2. Augustus is mentioned again in A.8.675-681:
in medio classis aeratas, Actia bella, cernere erat, totumque instructo Marte uideres feruere Leucaten auroque effulgere fluctus.
hinc Augustus agens Italos in proelia Caesar cum patribus populoque, penatibus et magnis dis, stans celsa in puppi, geminas cui tempora flammas laeta uomunt patriumque aperitur uertice sidus.
(in the middle it was possible to see the ships covered with bronze, the battle of Actium, and you could see the whole of Leucate swarming with numbers in Mars' order of battle, and the waves glowing with gold. Here Caesar Augustus standing on the high stern leads the Italians into battle, together with Senate and people, the Penates and the mighty gods; his cheerful face pours out double flames, and on his head his father's star is revealed)

Whether Octavian played such a heroic part at Actium is a moot question, but fortunately Agrippa, his loyal general and admiral, was there: parte alia uentis et dis Agrippa secundis/arduus agmen agens: (Elsewhere, with favourable winds and with the help of the gods, mighty Agrippa leads his force) $(A .8 .682-683)^{127}$. Vergil's description of Aeneas' shield ends with a jubilant prophecy of the greatness of the new ruler. In A.8.714-728, he tells us of Octavian's triple triumph in 29 B.C. when he celebrated his victories in the Illyrian campaign, in the sea battle of Actium and the final surrender of Antony and Cleopatra at Alexandria. Lines 714-715, and 720-728 say:

at Caesar, triplici inuectus Romana triumpho moenia, [...]. ipse sedens niueo candentis limine Phoebi dona recognoscit populorum aptatque superbis postibus; incedunt uictae longo ordine gentes, quam uariae linguis, habitu tam uestis et armis. hic Nomadum genus et discinctos Mulciber Afros, hic Lelegas Carasque sagittiferosque Gelonos

127 In Epod.9 Horace also refers to Octavian's lack of courage. 
finxerat; Euphrates ibat iam mollior undis,

extremique hominum Morini, Rhenusque bicornis,

indomitique Dahae, et pontem indignatus Araxes.

(But Caesar, who had entered the walls of Rome in triple triumph. He himself, seated at the white marble entrance of shining Phoebus, surveys the gifts of nations and fastens them on the high doors; the conquered peoples pass along in a long column, as diverse in languages as in fashion of dress and arms. Here Mulciber had arranged the Nomad race and the ungirt Africans, there the Leleges and Carians and the Gelonians, armed with arrows; the Euphrates moved now with calmer waves, and the Morini, remotest of man, passed along, and the Rhine with double horn, the untamed Dahae, and the Araxes indignant at his bridge)

In this passage Vergil uses his poetic licence to the full. Octavian could not have been seated niueo candentis limine Phoebi (at the white marble entrance of shining Phoebus) as the temple of Apollo was not ready before 28 B.C.. According to Miller $(2009,65)$ this is a "famous anachronism" and the temple of Apollo is a substitute for that of Iuppiter Capitolinus (McKay, 1998, 211; Miller, 2009, 54-94, esp. at 65, 75 and 208). Moreover, Vergil mentions a pot-pourri of peoples that cannot have been present at Octavian's actual triumph, as he mixes adversaries of Octavian at Actium with those of later dates. Some peoples are referred to by their names, while other peoples are represented by the rivers which border on their territories (Euphrates, Rhine, Araxes). Some came from Africa, such as the Nomads, who had come with Bogudes, king of Mauretania and ally of Antony. Others came from the East: the Leleges and the Carians from the southwest of Asia Minor, the Gelonians all the way from the Dnepr, and the Dahae, a people from Scythia. From the West came the Morini, from the region of modern Calais.

Vergil presents three categories of peoples. Firstly, there are conquered peoples (uictae gentes), who, after military defeat, were placed under Roman rule. Secondly, there are peoples who had been conquered, but who for strategic or economic reasons received special attention from the Roman authorities in order to be rehabilitated, as was the case with the Leleges and Carians. However, not all of the peoples which are identified or represented by rivers had been conquered and pacified, and Vergil's third category consists of the peoples which had not been subjugated yet (indomiti) and for whose members the Romans had a healthy respect. This is the case of the Dahae, who indicate the formidable force of the Parthian cavalry, and the Armenians, represented by the Araxes. The latter were initially allied to Rome, but soon after the battle of Carrhae a Parthian army invaded Armenia, and the Armenian king Artavasdes joined the Parthians, thus revoking the treaty with Rome. In line 727, Vergil also mentions the Rhenus bicornis (the Rhine of double horn), a reference to the point near Nijmegen, where the river divides in Rhine and Waal. This represents the inhabitants of the region, the Batavians ${ }^{128}$. Writing some years

128 Eden (1975, 190-191); Fordyce \& Christie (1977, 287); Miller (2009, 208-210); Page (1962b, 249-250). For the Eastern peoples, see Bivar (1983, 48-56, esp. at 55). For the Leleges and Cares, see Fordyce \& Christie (1977, 286). A detailed discussion of this passage is given in: Weeda \& van der Poel (2014, 
after the triumph, Vergil used his mythical prophecy of the peoples in the triumphal procession not only to symbolize the extent of the empire, but also as a functional reference to his vision of a stable and peaceful future under Octavian's leadership. The three categories of peoples indicate the political astuteness that is required to manage the empire: the political and military relations with the conquered peoples differ greatly from those with the peoples at the Eastern and Western borders. In the latter situations the leadership in Rome must make decisions which are tailormade for the particular threat in a specific border region. It is also interesting to note what Vergil has omitted. For example, he does not mention that Cleopatra's effigy was paraded in the procession, and the Egyptians do not feature among the peoples displayed in the triumph. These omissions show the poet's charitable attitude towards the queen.

Aeneas' shield shows not only the glory of war, but also the horrors, such as the rape of the Sabine women in A.8.635-637, the dismemberment of the traitor and coward Mettus Fuffetius in A.8.642-645 and the more recent history and civil strife represented by Catilina in A.8.668-669. The horrors of civil war had preoccupied Vergil for a long time and he had often vented his sorrow and indignation in the Eclogues and the Georgics. However, Iuppiter's promises in the first book of the Aeneid (1.254-296) were being kept and Vergil's description of Aeneas' shield voices his hopes of better times, gradually turning into expectations of better times.

The Aeneid also contains many indirect references to Augustus, for example A.6.69-70. The passage describes the temple which Aeneas had promised Apollo, which probably refers to the temple on the Palatine dedicated by Augustus in 28 B.C., as well as to the Apollonian Games set up in 212 B.C.. The passage reads: tum Phoebo et Triuiae solido de marmore templum/instituam festosque dies de nomine Phoebi (I will then found a temple of solid marble to Phoebus and Trivia, and institute festal days in Phoebus' name). Vergil also refers indirectly to Augustus in his description of Aeneas visiting the Hades where he meets young Marcellus, in A.6.860-886. The poet portrays the grief felt in Rome after Marcellus' death, and his interment in Augustus' new-built mausoleum. The connection of Marcellus, who as the son of Octavia and husband of Julia the Elder was being groomed as Augustus' successor, with Augustus' tomb signifies, on the one hand, the fragility of the hereditary system, and on the other Vergil mourning the death of a promising young man, and deploring the loss of a worthy potential successor to the princeps ${ }^{129}$. There are many more references to Augustus in the ways in which Vergil depicts Aeneas, and this raises the question

588-612). In this paper, it is argued that Vergil's use of the words Rhenus bicornis in line 727 and the manner in which he places these words within the context of lines $722-728$ mean that the poet refers to the inhabitants of the Nijmegen region.

129 Hardie (2000, 317-318); Page (1962a, 500-504); Williams (2006a, 513-516). See also Shackleton Bailey (1986, 199-205) on A.6.882-883: tu Marcellus eris. 
whether Augustus was a functional model for Aeneas in the same way as Cleopatra was for Dido. This is very likely, and I will discuss this in more detail in section 4.2.6.

There is not just praise for Augustus in the Aeneid. Vergil underwent a development in his attitude towards Augustus, and this is visible in the Aeneid. He extolled the virtues of Augustus, as the right man to bring peace and stability, but privately his sympathy was with the suffering and sorrow of many of the characters in the poem ${ }^{130}$. Vergil held a positive view of Aeneas, and consequently of Augustus, which is particularly visible in the first books. This positive view can be seen, for example, in Iuppiter's revelation of Rome's future in A.1.254-296 and in the prophecy of Anchises in A.6.789-795. However, in the same book (A.6.847-853), Vergil expressed a concern about the price of imperial success, which amounts to criticism of the new era. He felt that, as imperial conquerors, the Romans paid a high price. This is expressed the famous passages in which the Romans are given their marching orders, namely parcere subiectis et debellare superbos (to pardon the vanquished and to vanquish the proud). As Griffin (1979, 65-66) says: "This unrivalled speech [A.6.847-853] is at once a boast and a lament, a proud claim by a conqueror and a sigh of regret for the cost." Vergil is not anti-Augustan, but he is clearly unhappy with the way things are going. The passage says:

excudent alii spirantia mollius aera

(credo equidem), uiuos ducent de marmore uultus,

orabunt causas melius, caelique meatus

describent radio et surgentia sidera dicent:

tu regere imperio populos, Romane, memento

(hae tibi erunt artes), pacique imponere morem,

parcere subiectis et debellare superbos.

(Others, I trust, shall forge the bronze more easily to breathing, bring in the marble lifelike features, plead cases better, and with a rod sketch off heaven's motions and predict the rising of the stars: you, Roman, do not fail to rule the nations (that will be your skill) and to add civilisation to peace, to pardon the vanquished and to vanquish the proud)

The alii are the Greek, the masters of art. For the Romans there remain the hard arts of conquest and dominion. This passage contains explicit criticism of the new age. According to Griffin $(1979,68)$ this criticism is that:

130 Stahl (1993, 174-211) quotes a number of scholars, among others, Quinn, 1968 and R.D. Williams, 2006, who wrote in the sixties of the last century about the public and private voices of Vergil. He quotes Williams (2006a, xxi): "But side by side with his [Vergil's] public voice is the private voice, expressing deep concern for the lonely individual who does not fit into these cosmic schemes.” 
In the Aeneid Virgil has succeeded in devising ways of bringing out this complex of ideas, central to his vision of Rome and of history: of Roman destiny as an austere and self-denying one, restraining furor and superbia, and imposing peace and civilization on the world; at the cost of turning away, with tears but with unshakable resolution, from the life of pleasure, of art, and of love.

In the Aeneid, there is also much violence brought about by Aeneas and his men. Dominik $(2009,127)$ gives a detailed list, from which I select here some of the acts of violence which are Aeneas' responsibility. In: A.10.310-311, primus turmas inuasit agrestis/Aeneas (first Aeneas attacked the crowds of peasants), we see Aeneas in the battle against Turnus, perhaps referring to Octavian's expropriations after Philippi. One also reads about violence in A.11.100-105, for instance in line 102 corpora, per campos ferro quae fusa iacebant (bodies that lay dead by the sword spread all over the plain), and in A.11.372-373, inhumata infletaque turba,/sternamur campis (let us be scattered over the fields, a mob unburied and unlamented). In A.12.35-36, we read Latinus' words that recalent nostro Thybrina fluenta/sanguine adhuc campique ingentes ossibus albent (until now Tiber's streams remain warm with our blood, and the vast plains are still white with our bones). Dominik $(2009,127)$ summarises this as "the intrusion of the politico-military world of the Trojans into the life of the Italian countryside and its inhabitants precipitates violence, war, and death on an unprecedented scale." I interpret Vergil's aversion to and condemnation of the violence of Aeneas as a reference to Octavian's line of conduct in the civil war. Just as Aeneas did his duty and founded Rome, Octavian did his by establishing order by military force. Nonetheless, the poet condemns the unnecessary destruction and cruelty.

The finale of a poem has a special significance: the poet has a last opportunity to make his point ${ }^{131}$. Vergil does just that when he describes the death of Turnus and the events preceding it, such as the felling of a sacred olive tree by Aeneas' troops in A.12.770-771: sed stirpem Teucri nullo discrimine sacrum/sustulerant, puro ut possent concurrere campo (but the Teucrians had cut down without respect the sacred tree, so that they could fight on open ground). Although the perpetrator of the violation is Aeneas, A.12.766-771 can be interpreted as an indirect reference to Octavian's violation of the Italian countryside at the end of the civil war, a theme which we often encounter in the Eclogues.

Aeneas has to fulfil his duty and cannot allow his adversary Turnus to continue to challenge him. He has been charged by the gods with establishing his new realm and Turnus has to submit. The power of arms will decide. When, in the final clash between the two, Turnus is forced down on his knees and begs Aeneas for mercy, the latter notices the belt of young Pallas on Turnus' shoulders. In the last eight lines of the epic (A.12.945-952) Aeneas changes into a merciless victor. These last lines are:

131 Horsfall (1995, 192-216); Putnam (2011, 101-117); Rijser (2011, 135-150); Tarrant (2012, 16-30, 327341). 
ille, oculis postquam saeui monimenta doloris

exuuiasque hausit, furiis accensus et ira

terribilis: 'tune hinc spoliis indute meorum

eripiare mihi? Pallas te hoc uulnere, Pallas

immolat et poenam scelerato ex sanguine sumit.'

hoc dicens ferrum aduerso sub pectore condit

feruidus. ast illi soluuntur frigore membra

uitaque cum gemitu fugit indignata sub umbras.

(as soon as Aeneas absorbed with his eyes the spoils, reminder of cruel grief, he cried out, inflamed with fury and terrible in wrath: "you, decked out in the spoils of one of mine, escape me? Pallas sacrifies you with this blow, Pallas repays you for your guilty blood!" That is what he said, and in burning rage he sank his sword deep in the breast before him. His [Turnus'] limbs gave way by the cold; his life fled indignantly with a sigh to the shadows of death)

A much discussed question is whether it is necessary to kill Turnus in such a brutal way, feruidus et ira terribilis (inflamed with fury and terrible in wrath). Is Aeneas' action lawful or does Aeneas shed too much blood? Galinsky discusses in detail the question of permissible anger. He examines the views in Rome at the time of Augustus and the philosophical origins of permissible anger in Aristotle, Plato, the Epicureans and the Stoics. He $(1988,331)$ states that "later Roman law incorporated many of Aristotle's ideas on the responsibility for acts committed during emotion." 132 In the Nicomachean Ethics 1149a25-1149b27, Aristotle gave four reasons why a lack of restraint due to anger is less to blame than lack of restraint due to other emotions. Galinsky (1988, 331-332) summarises:

\begin{abstract}
first, anger is based on a judgement, [...]. Secondly, anger is more "natural" than a desire for excessive and unnecessary pleasures. Nobody would argue that Aeneas engages in a pleasurable act. Thirdly, anger is an open response, and not crafty and dissimulating. It is good to keep this in mind when one reads critics who insist that Aeneas, if he needs to kill Turnus, at least should do it with less emotion. And fourth, anger is accompanied by pain (e.g., due to the provocation) and is not engaged in simply for the pleasure of it.
\end{abstract}

Galinsky $(1988,339)$ also remarks that “in sum, so far from finding Aeneas' anger repugnant, most of the ancient ethical tradition would find it entirely appropriate and even praiseworthy. After the breach of the foedus earlier in Book 12, Aeneas has every reason to respond with anger."

I have reservations about Galinsky’s arguments. Vergil uses very specific words to describe Aeneas' state of mind, which suggest that Aeneas has temporarily lost his faculty of judgement. Firstly, in lines 946-947 the words furiis accensus et ira terribilis (inflamed with fury and terrible in wrath) are applied to Aeneas. Putnam $(2011,109)$ pointing out the similarities between Dido in book 4 (A.4.376 furiis incensa, set on fire

132 For the anger of Aeneas, see: Galinsky, 1988; Lowrie (2009, 163); Putnam (2011, 102-117); Tarrant (2012, 9-30). 
by fury) and Aeneas in the last lines of the book (A.12.946, furiis accensus, inflamed with fury), states that:

as we look at the end of the Aeneid through the prism of the emotional world that Virgil creates for Dido and which stays with us throughout the epic, Aeneas both becomes her and kills her as he slays Turnus, but with one major difference. Dido is the passive victim of furies who opts for self-slaughter. Aeneas is equally a prey to madness but turns its violent manifestation onto his suppliant opponent.

I will argue in section 4.2.3 (see note 156) that, by loosing self-control, Dido - like Aeneas in the passage above - did not act as a good queen should. This shows "the humanness of heroes” (Putnam, 2011), both for Aeneas and for Dido. Tarrant (2012, 337) observes that "Virgil's language contains no overt condemnation of Aeneas, but the image of him 'inflamed with furious rage' is undeniably disturbing. [...] Neither furiae nor accendere is elsewhere applied to Aeneas in Virgil's own voice." Vergil uses words like furia at other places, even twice in A.12.680 when Turnus tells his sister that he is ready to meet Aeneas for the final confrontation: hunc, oro, sine me furere ante furorem (pray, allow me first to be furious in this madness). The poet portrays Turnus' uncontrolled fury in the following lines (681-696), comparing the raging Turnus to a rock coming loose from a mountaintop. Vergil did not condemn furia as such. He used the word furia to describe justified anger in, for instance, A.8.494, when king Euander describes how Etruria rose in furiis iustis (righteous fury) against their cruel despot Mezentius, who found shelter with Turnus, his friend. Aeneas' ira is characterised by the poet as ira terribilis. Although Vergil understood Aeneas' anger, the specific qualification of the anger as terribilis suggests that it was excessive, as his victim Turnus was lying wounded before him.

According to Tarrant $(2012,19)$ Vergil "highlights the intense emotional state into which Aeneas is thrown by the sight of Pallas' belt.” The poet makes the point that Aeneas has lost his self-control, and thus is no longer able to act on judgement: Aeneas does not meet Aristotle's first requirement. Vergil levels his criticism not at the killing of Turnus, but specifically at the brutal manner in which it is carried out. Stahl $(1993,210)$ states: "my conclusion then would be not only that Vergil fully agrees (and wishes to guide his reader to the same position) with Aeneas' act of killing Turnus, but views it as the only morally justified solution to his epic." I concur with his view that Vergil agrees with the killing of Turnus, but Vergil suggests that the moral justification is tainted by the brutality of the killing. This corresponds with the poet's view that war is a messy business, in which men - Augustus and Aeneas alike when involved in war - show their weakness, and which always results in cruelty and violence. As Quinn (1979, 67-68) points out when he discusses the final passage of the Aeneid:

True, Turnus must be got rid of: however humane the gesture if Aeneas had spared his life, it would be dramatically and poetically intolerable for Turnus to survive to fight another day. Aeneas' victory leaves no place for Turnus. But Aeneas does not have to kill his enemy in a mad 
blaze of anger. He kills Turnus in revenge, as the agent of a personal vendetta, not as the agent of the destined victory of his people. [...] Instead of asking them [the critics, the students of Greek tragedy, the philosophers in that original audience, [...] and others less sophisticated] to criticize Aeneas, was not Virgil asking his audience to admit to themselves that by the time final victory comes, no man, least of all perhaps the leader of the winning side, can hope to count his hands or his conscience clean ${ }^{133}$

Quinn suggests that Vergil depicts good king-Aeneas as a human being with his ugly sides. Tarrant $(2012,27)$, however, sees the final scene of the Aeneid as "typical of Virgil's double-sided outlook to remind his readers of the bloody past of their princeps while also looking to him as the author of peace."

Losing self-control turns Aeneas from a good king into a bad king, similar to Dido losing self-control in her fury when she inveighs against Aeneas at his departure from Carthage (see section 4.2.3). The view which Vergil takes of Aeneas at the end of the epic also reflects badly on Augustus. Indeed, I interpret this passage as an allusive reference to Augustus, implying criticism of him. As mentioned above, Anchises impressed upon his son the moral attitude of an honourable and just Roman leader in A.6.851-853:

tu regere imperio populos, Romane, memento

(hae tibi erunt artes), pacique imponere morem, parcere subiectis et debellare superbos.

(you, Roman, do not fail to rule the nations (that will be your skill) and to add civilisation to peace, to pardon the vanquished and to vanquish the proud)

In lines A.12.933-934, Turnus, reminding Aeneas of his father's words, threw himself on his mercy in vain; Aeneas ignored his father's words and plunged his sword into Turnus' chest. Romane means that Anchises especially urged the modern Romans who were busy building the empire to show compassion. Romane makes these lines a functional reference to Augustus' lack of compassion. As Putnam (2011, 116-117) puts it in his elucidating chapter on the ending (of the Aeneid):

What would Aeneas's disobedient, furious killing have meant to the princeps himself? How does it complement the expected glory of Rome, present and to come? [...] At his epic's finale the poet does not put before us someone literally, or figuratively, throwing away his weapons, as Anchises asks of Pompey and, above all, of Caesar in book 6. Rather, he presents us with a vivid illustration of anger-driven vengeance at work, [...]. This account is not to the liking of those who wish to see Aeneas as a paradigm for the just and noble ruler, as a model for Roman leaders to come.

Rijser (2011, 139-147) also addresses the question of the meaning of the closure of the Aeneid. Citing Putnam's “What would Aeneas's disobedient, furious killing have meant to the princeps himself?" question, he $(2011,141)$ states:

133 My emphasis. 
if we trust the antique testimonia, the Aeneid was indeed what the princeps wanted; and yet that same Aeneid contains the open and painful questions about Roman rule that Putnam has shown to be there without doubt. In that case, what Augustus wanted must have been exactly that: not a simple panegyrical text, but a layered, multi-vocal one that explained the tribulations he had sought to end, the blood of which was still damp on his hands. Such a work might include tragic conflict, even the suggestion of guilt. To accommodate that suggestion, we must of course discard or at least modify the idea of Augustus the tyrant, and move toward a more civilized, perhaps even sensitive and certainly very intelligent Augustus.

In other words: Augustus could live with such criticism. I will argue in the fifth chapter that Vergil was a commentator who was both critical and supportive.

Augustus had also been accused of cruelty in the civil war, for instance in the case of the farmers' evictions from their land, which had caused many casualties, and even worse in the slaughter at the surrender of Perusia. The Aeneid contains many ambivalent passages in which Vergil both lauds and criticises Augustus. This shows that the poet's objective was probably not only to write an epic about the mythical foundation of Rome, but also to give his commentary on contemporary issues. One finds in the Aeneid many direct and indirect references to politically significant events, such as the war with Cleopatra and Antony, the emergence of the Principate, the sufferings caused by the civil war and Augustus' conduct in war. This "double-sided outlook" caused Tarrant (2012, 27, note 111) to suggest that "it seems possible that even as early as 19 [B.C.] Virgil could have felt that the tone of the Aeneid was now too dark for the times; might that have been a factor in his dying impulse to destroy it ?" I agree with Putnam's suggestion that - if Vergil had in fact ever felt any wish to have the manuscript of the Aeneid destroyed - this wish "would more likely arise from his worry about the moral quality of that empire's headship and therefore of the Roman Empire itself, or of any empire" (Putnam, 2011, 116). Vergil felt that the necessary fundamental changes should not be achieved at the cost of great suffering by some or result in the loss of traditional moral values. His involvement was more than mere concern. It is unlikely that on his deathbed Vergil would have changed his beliefs, which he held during his whole writing career and which we read in the Eclogues and the Georgics as much as in the closing lines of the Aeneid. Why should the latter be destroyed - after his death - when his views had been there for all to read for the last decades?

At the end of the book (section 5.1), I will discuss his political views in more detail. 


\subsubsection{References To Cleopatra}

Many direct references to Cleopatra can also be found in the Aeneid ${ }^{134}$. The best known passage is in A.8.608-731. This is: the story of the new shield made by Vulcan which Aeneas received from his mother Venus. Although Cleopatra remains unnamed in this passage, there is no doubt that Vergil is writing about her. Antony is mentioned by name (line 685) and Cleopatra is connected with him in line 688. In the course of his description of the history of Rome, which takes up virtually the remainder of book 8 (A.8.626-728), Vergil relates the important events up until his own days. The Egyptian queen appears three times in A.8.671-713, a passage which deals with Actium and its aftermath. Cleopatra is referred to for the first time in A.8.685-688: Antonius [...], sequiturque (nefas) Aegyptia coniunx (Antony, and there follows him (disgrace) his Egyptian wife) $(A .8 .688)^{135}$. According to Harrison Cleopatra is a nefas (abomination): "Cleopatra herself, attempting to do the unspeakable in overcoming Augustus and becoming mistress of Rome as Antony's wife” (Harrison1998, 235). However, like Binder (1971, 235), I interpret nefas as referring to Antony's liaison, because it was for Romans not a legitimate marriage, and particularly to his acquiescence to the queen's command of Roman soldiers at Actium. Cleopatra appears again in A.8.696-700:

regina in mediis patrio uocat agmina sistro,

necdum etiam geminos a tergo respicit anguis.

omnigenumque deum monstra et latrator Anubis

contra Neptunum et Venerem contraque Mineruam

tela tenent. [...]

(In the middle of this the queen calls upon her troops with her native rattle; she does still not look back at the twin snakes behind. Divine portents of every kind and the dog Anubis, the shadow of death, hold weapons against Neptune and Venus and against Minerva)

This passage is often quoted by many modern scholars as an example of the low regard in which Vergil held Cleopatra ${ }^{136}$. Reinhold (1981/1982, 97), who refers not only to A.8.696-700, but also to HOR.Carm.1.37.6-14 (Horace's “Cleopatra Ode”), and to PROP.3.11.30-58, states: "The savage propaganda campaign unleashed [by Octavian in 32 B.C.] against Cleopatra poured out a flood of extravagant indictments

134 Parts of this section and sections 4.2.3-4.2.5 were originally written as a paper entitled "Vergil and Cleopatra” together with professor Marc van der Poel (Radboud Universiteit Nijmegen).

135 On Aeneas' shield see: Hardie (1989, 97-109, 120-125, 336-376); McKay, 1998. Chaudhuri, 2012 presents an interesting view on Vergil's concealment of the name of Cleopatra by wordplay. It is unlikely that Vergil used this instrument here, as he refers rather directly to Cleopatra.

136 On Vergil's views of Cleopatra see: Kleiner (2005b, 191); Schäfer (2006, 11-12, 229-230); Syed, 2005; Williams (2006b, 273); Wyke (2004, 104-105). For the propaganda against Cleopatra by Augustus and the poets see: Kleiner (2005b, 112, 136-137, 274); Oliensis (2007, 226); Pomeroy (1984, 24-28); Wyke (2004, 98-140). 
and recriminations (lust, whoring, incest, use of magic and drugs, drunkenness, animal worship, rampant luxury) that have echoed down through the ages in history, literature, and the popular image of her.” According to Wyke (2004, 104):

Neither daughter, wife nor mother, Cleopatra has scarcely any physical presence at all in the Horatian and Virgilian narratives. At best the queen is drunk with sweet success (Ode 1.37.11-12) or pale with fear of her coming death (Aen.8.709). Only barking Anubis and the rattling sistrum which, in the Aeneid, accompany the queen into battle might suggest the dissonance of barbarian speech.

Kleiner (2005b, 191) writes about this passage: "In the Aeneid, for example, Virgil describes Cleopatra trailed by a motley array of Egyptian deities with an animalistic nature - a strong contrast to the august stature of the core Roman divinities." Syed $(2005,181)$, focusing on gender and ethnicity and arguing ethnic differences, asserts that this passage "articulates the profound otherness of Octavian's enemies in ethnic and national terms, [albeit] an articulation that is overdetermined precisely because it has to overcome the taint of civil strife inherent in a battle between two Roman generals.” Schäfer (2006, 229-230), quoting large parts of A.8.671-710, states:

Und jetzt ging es natürlich erst einmal an die Verherrlichung des Sieges, [...]. Aber wie so oft, entscheidend ist nicht, was passiert, sondern wie man darüber redet. Und in dieser Hinsicht konnte sich der spätere Augustus auf die römischen Dichter verlassen. Horaz widmete Actium eine euphorische Ode. In Vergils Epos wurde sogar eine Darstellung beschrieben, die auf dem Schild des Aeneas zu sehen gewesen sei und den Charakter einer Prophezeiung besa $\beta^{137}$.

Significantly, Schäfer omits lines 698-701 about the Egyptian and Roman gods: two lines which can be interpreted as casting Cleopatra in a more positive light ${ }^{138}$.

Hardie (1989, 336-376) argued rightly that Vergil's focus in this part of book 8 is on the history of Rome. Hardie $(1989,348)$ states: "the ecphrasis (like the whole of book eight) is essentially concerned with Roman, not Italian, history, and with the growth of the city of Rome to become the world-power." I agree with Hardie's analysis of Vergil's motives and I read the same focus in this part of the Aeneid. However, Vergil's portrayal of the sea battle has fewer supernatural Gigantomachic aspects than Hardie sees. In

137 And yet, the emphasis was of course firstly on the glorification of the victory, [...]. As often, what happened is not the point, but rather the way one talks about it. In this respect, Augustus could afterwards rely on the Roman poets. Horace dedicated a euphoric Ode to Actium. Vergil's epic contained even a description with features of a prophecy, which was to be seen on Aeneas' shield.

138 Schäfer $(2006,248)$ refers also to $A .8 .697$, suggesting that this line describes Cleopatra's effigy in the procession of Octavian's Triple Triumph in 29 B.C.. Schäfer states: "indem er bei seinem Triumph über Ägypten ein Bild Kleopatras mit zwei angelegten Uräusschlangen mittragen ließ.” (because he [Octavian] carried in the procession after his triumph over Egypt a statue of Cleopatra with two cobras laid against her). However, the anguis in line 697 symbolizes the threat of death for Cleopatra during the battle of Actium. 
essence, it is a narrative in which the poet describes the events rather realistically. Thus, I do not share Hardie's and other scholars' interpretation of, for example A.8.696700, according to which Vergil describes in this passage the clash of two worlds, the evil East and the superior West. In my opinion it is much less complicated.

So how to interpret A.8.696-700? Firstly, although omnigenumque deum monstra in line 698 is generally rendered as "monstrous gods of every form” (Loeb), monstrum also originally means a divine omen indicating misfortune, an evil omen, or a portent, which is the meaning in for example A.3.59 (monstra deum refero (I bring the divine portents) $)^{139}$. Secondly, Anubis' presence concurs with these evil omens. Anubis, the Egyptian god, represented with a dog's head, is a god of the realm of the dead and in particular the accuser of souls at the final judgement after death. Therefore, I prefer to render A.8.697-700 as: "she does still not look back at the twin snakes behind. Divine portents of every kind and the dog Anubis, the shadow of death, hold weapons against Neptune and Venus and against Minerva.” Accordingly, the lines express that Cleopatra at that stage of the battle is not yet aware that she is fighting under the threat of imminent death, aided only by her Egyptian divine evil omens and not by powerful gods. The Egyptians fought against superior Roman forces who were aided by their gods: "Neptune, the god of the sea where the battle takes place, Venus, the mother of the Roman race, Minerva the goddess of wisdom.” (R.D. Williams, 2006, 273). Thus, I interpret the symbolism of lines 697-698 as expressing Vergil's compassion for the approaching death of a courageous Cleopatra, and not "the conflict of religious attitudes between East and West.” (R.D. Williams, 2006, 273). Gurval (1998, 237) hints at this interpretation by pointing out that Vergil alludes to Dido, when he states that there is some reminiscence with Dido: "like Dido [...], the Egyptian queen is also fated to die." In the next passage there is also textual similarity with Dido (Gurval, 1998, 240). In A.8.709 we read that Cleopatra was pallentem morte futura (pale at the coming of her death) and in A.4.644 Dido is described as pallida morte futura. Gurval, however, does not suggest that Vergil used Cleopatra as a model for Dido.

139 For "the monstrous gods" see for example: Conington \& Nettleship (1963, 154): "expressing a Roman's contempt for the heterogeneous assemblies of deities”; Fordyce \& Christie (1977, 283): “in the language of familiar abuse”; Gransden (1976, 179): “The monstrous and barbarous deities of Egypt are here arrayed"; Page (1962, 248): "for the 'monstrous gods' of Egypt see Juv. 15 ad in”; Pease (1967, 26-27): "monsters described as worshipped by the Egyptian queen”. Fordyce \& Christie refer for the use of monstrum in A.7.21, where they interpret monstrum rightly as "originally a religious term used of a supernatural phenomenon which conveys a portent or an omen", and give five places in the Aeneid and two in the Georgics where Vergil used monstrum meaning portent/omen (Fordyce \& Christie, 1977, 58). Contrary to our opinion, they do not suggest that the latter meaning of monstrum also applies to the present passage; Hardie $(1989,98)$ : “The Virgilian battle [Actium] is between two quite separate races of gods, the Roman Olympians and the alien Egytian divinities, monstrous and non-anthropomorphic (Aen.8.698).” Hardie $(1989,104)$ repeats “the monstrous forces”; Williams (2006b [orig. 1996], 273): "Anubis [...] who exemplifies the various monstrous shapes in which their [Egyptian] gods were visualized.” Finally, McKay $(1998,210)$ is rather neutral: “bestial, barking Anubis.” 
The culmination of all this is found in a third passage where Cleopatra's flight to Egypt is described (in A.8.707-713):

\begin{abstract}
ipsa uidebatur uentis regina uocatis
uela dare et laxos iam iamque immittere funis.

illam inter caedes pallentem morte futura

fecerat ignipotens undis et Iapyge ferri,

contra autem magno maerentem corpore Nilum

pandentemque sinus et tota ueste uocantem

caeruleum in gremium latebrosaque flumina uictos.

(The queen herself was depicted challenging the winds, spread sail, and now, yes now, slacken and let go the ropes. Amid the slaughter, pale at the coming of her death, the Ruler of fire had represented that great queen, carried off by waves and by the wind that blows from the South of Italia; he had made in front of her the mourning Nile with his great body, spreading open the folds of his gown and welcoming with the whole of his garment the defeated to his blue lap and sheltering streams, full of coverts)
\end{abstract}

Modern commentators argue that in his account of the battle at Actium (lines 671-713), Vergil - compelled by Octavian's propaganda - presents Cleopatra as worshipping animalistic deities (Kleiner, 2005b, 191; Reinhold, 1981/1982, 97), as being a barbarian (Wyke, 2004, 104), or as having a shameful liaison with Antony (Binder, 1971, 235; Harrison, 1998, 235). On the contrary, I suggest that in this passage, Vergil presents Cleopatra with restraint. His words show kindness, awareness of her emotions and compassion with her fear, even panic, particularly when he portrays her pallor and the shadow of death hanging over her. Particularly impressive is the image of the mourning Nile, standing for Egypt, and of its streams giving shelter to the great queen in her defeat. It is unlikely that these lines are the fruits of Octavian's propaganda. The latter is supposed to have presented the final stages of the civil war (after 35 B.C.) as a conflict with an external foe, Cleopatra. It is abundantly clear, however, that, in line 685, it is Antony who leads the forces against Octavian at Actium, hinc ope barbarica uariisque Antonius armis (on the other side Antony with his foreign might and his mix of troops), and that Cleopatra takes second place in line 688, sequiturque Aegyptia coniunx (follows him his Egyptian wife). Syed (2005, 179) emphasizes the "orientalization of his [Antony's] entourage." In her opinion, the oriental nature of Antony's (and Cleopatra's) army had "a powerful impact on the ideological polarization of the two enemies represented here." This "otherness" of Antony's forces is part of her $(2005,180)$ argument that "otherness is stressed [by Vergil] in national terms, which in turn have a defining force for the Romanness constructed in this passage." Syed $(2005,179)$ is right in arguing that Vergil's representation of Antony's forces at Actium "has little or no basis in historical fact." His description of the presence of oriental forces is indeed exaggerated. I would suggest, however, that Vergil used this caricature for a very different purpose, that is to ridicule Antony's position in Alexandria and his failed Eastern ambitions. 
The afore mentioned passages contain direct references to Cleopatra. The story of Pallas' sword-belt in A.10.495-498 can be interpreted as an allusive reference to the queen:

et laeuo pressit pede talia fatus

exanimem rapiens immania pondera baltei

impressumque nefas: una sub nocte iugali

caesa manus iuuenum foede thalamique cruenti,

(And while he [Turnus] said this, he stood with his left foot upon the lifeless body [of Pallas], seizing the belt with it's enormous weight and the crime engraved on it: the group of young men slaughtered cruelly on one wedding night, and the bridal-chambers stained with blood)

On this belt is depicted the myth of the Danaids: the fifty daughters of the EgyptoGreek king Danaus who were married to their cousins and who - with one exception - slaughtered their newly-wed husbands on their wedding night. Clearly, the myth is symbolic here, and there has been much discussion about the nature of the symbolism. In Kellum's (1985, 172-175) opinion, the above lines demonstrate that the poet portrays the darker side of Cleopatra. She argues that the Danaids represent the evil forces of oriental barbarism, defeated at Actium. According to Harrison $(1998,234)$ the spousemurdering Danaids of Egypto-Greek origin "are surely an appropriate mythological representation of Cleopatra, the official enemy at Actium, defeated through Apollo's help in the Augustan accounts of the battle." This refers to Cleopatra, who had murdered two of her younger brothers, who were also her husbands: the first Ptolemy XIII in 51 and the second Ptolemy XIV in 44 B.C. ${ }^{140}$. Obviously, Vergil does not paint a flattering picture of Cleopatra in this passage. However, he probably interpreted these murders within the contemporary context. First, Cleopatra acted in the true fashion of Hellenistic monarchs. Second, many opponents of the political leadership in Rome were also murdered, in particular during the proscriptions. Third, Cleopatra, by eliminating her political rivals, does not differ essentially from Octavian, who had both Antyllus, Fulvia's elder son by Marc Antony, and Caesarion murdered, and who had forced Gallus to commit suicide, to mention only a few examples (cf. Pomeroy, 1975, 124, 186-187).

140 Harrison (1998, 223-242) gives an extensive discussion of the different views on the meaning of the symbolism. A discussion of Roman attitudes towards other peoples is given in Isaac (2004, 359, 369-370). One can also interpret this passage as a reference to Dido. In preceding book 10 Vergil refers to similar negative traits of Dido, for example in A.4.584-629, when she threatens to murder Ascanius, curses Aeneas, and prays for ongoing hostility between her people and Aeneas' descendants. 


\subsection{Models In The Aeneid}

In section 1.2.3 I introduced the notions of the literary frame and the functional frame, and the concept of the functional model. In this section, I will argue that in the Aeneid Vergil used both literary and functional models. However, I will focus on the latter, as the literary model - in general and also in particular in the Aeneid - has been researched sufficiently and in great detail in many scholarly papers. In successive sections I will discuss the subject of models in the Aeneid in general (section 4.2.1), the question whether there ever was a Carthaginian queen Dido, who she was and the early myths (section 4.2.2), Dido in the Aeneid (section 4.2.3), models for Dido (section 4.2.4), the question whether Cleopatra was a functional model for Dido (section 4.2.5), and finally whether Augustus was a model for Aeneas (section 4.2.6).

\subsubsection{A General Introduction}

The leading characters in the Aeneid have acted as models for many others over a period of more than two thousand years. Did Vergil perhaps use models too? He was certainly inspired by Homer. But whether he had in mind models for his main characters is a different question. And if this is the case who was or were his model or models? Was Aeneas sufficiently known through mythical stories? Did Vergil use a model for Dido? Or was Dido a known figure? Did he perhaps use models for both? Other questions can be raised as well, such as: if Vergil used models, did he only choose them in order to present Augustus in a favourable light and through Aeneas foreshadow Augustus, or is the choice also a commentary on the social and political situation of his time?

In section 1.2.3 a distinction between the literary frame and the functional frame was introduced. Consequently, I distinguish between two forms of models: the literary model and the functional model. In both models the author describing a persona has a person in mind whose "parallel" in character, social position or physical appearance he uses. Similarly, when he depicts an event, the author uses what he considers an analogue.

I will use the term literary model when the author refers to a predecessor or an admired colleague-author. In that case, the poet's main objective is to create a literary continuity with his paragon by referring or alluding to the latter's work. In a functional model the author does not primarily have a literary objective. His main purpose is to deliver either a specific statement or a functional description of persons or events. These statements often concern political or social issues, and/or the actors in those fields. In a functional description the author intends to portray the nature of an issue, and/or the manner in which his persona acts. A functional description may also suggest the impact of the persona's actions. In the case of both persons and events the author may select a model generally renowned for the characteristics he wants to 
illustrate. Hence, the choice of a model for persons is often either a contemporary, a mythical or a well-known historical person who becomes the origin of associations in the readers' minds. As a consequence, when the model is an illustrious contemporary person, the author by implication alludes to this contemporary person. Explaining the major characters of the Aeneid and their actions, Binder $(1971,2)$ uses the words "typologische Auslegung" (typological interpretation), which is not synonymous but similar to my definition of functional models. With this he (Binder, 1971, 3) means that the personae in the Aeneid are like their models: "He [Augustus] is not Hercules or Aeneas, but he is as they are, their historical portrait." Therefore, in the epic there are poetic connections between the myth and the present which refer the reader to contemporary events.

Most modern scholars hold the view that Vergil employed a model when he described the mythical Dido and in the extensive literature on the subject much has been written about the different options, some of which mention Cleopatra ${ }^{141}$. It is likely that Vergil had two objectives. The first was the writing of an epic about the founding of Rome and its (mythical) history. For this purpose he found his inspiration in either Homer, the Greek tragedians, Apollonius Rhodos, or Ennius, or all four. Their work or works formed the literary model for the Aeneid, both for the architecture and for the personae and events ${ }^{142}$. The Aeneid contains numerous examples of literary models: I choose at random. Firstly, in A.1.496-504, where Aeneas meets Dido for the first time, Vergil likens her to Diana and her company. According to Nelis (2001, 8286) Vergil refers to both Artemis/Nausicaä (by means of the Homeric simile) in HOM. Od.6.102-108, and to Artemis/Medea in Argonautica.3.876, where Apollonius imitates Homer. Knauer $(1979,155)$, whose book is concerned with Homer as a model for the Aeneid, points out rightly that "Vergil konnte sie [Nausikaa] schwerlich als Gestalt in die Aeneis übernehmen, den Didos Gestalt hat andere Voraussetzungen ${ }^{143}$." Still, both references can be considered literary models for Dido, as Vergil creates a literary continuity with either Homer or Apollonius, or both ${ }^{144}$. A second example is the episode of the wounding of Dido in A.4.66-73. In Nelis' (2001, 25-180, esp. at 131-132) view this refers to Apollonius' depiction of Medea wounded by the arrow of Eros in the third book of the Argonautica. Nelis (2001, 5-21) refers to Vergil's literary debt to both Apollonius and Homer as "a pattern of two-tier allusion linking Vergil, Apollonius

141 In chronological order: Crees and Wordsworth (1927, xi); Pease (1967/1935, 24-28); Knauer (1964, 155, 209); Otis (1966, 62-96); Jones (1971, 118); La Penna (1985, 48-63, esp. at 54); Cairns (1989, 57); Easterling and Knox (1993, 58); Farron (1993, 61-62); Horsfall (1995, 133-134); Galinsky (2003, 17-23); Nelis, 2001; Griffin (2004, 183-197).

142 Hardie (2000, 312-326) and Tarrant (2012, 28-30), among other scholars, have pointed out that Vergil was not only inspired with respect to form, but that there was also much tragic influence.

143 Vergil could hardly adopt her [Nausikaa] as a model (Gestalt) in the Aeneid, as Dido's persona has different requirements.

144 See also Page (1962a, 188 [at A.1.498]), who mentions only Homer's text. 
and Homer." Nelis $(2001,7)$ states that he "will attempt to demonstrate that Vergil's epic is built out of a consistent, structured pattern of imitation based on awareness of Apollonius' imitation of the Iliad and Odyssey." In his book (2001, 5-9) he gives a wide selection of secondary literature on the use of models and references in Latin poetry. I will discuss Nelis' views about Medea as a model for Dido in more detail in section 4.2.4 $4^{145}$. Otis (1966, 71-76) also discusses the wounding of Dido: "There can thus be no doubt that Virgil is primarily indebted to Apollonius” (Otis 1966, 73).

I intend to demonstrate that it is likely that Vergil had an overriding second objective, which was political. This objective was to foreshadow and portray in his epic Augustus, whom he believed to be the leader who could bring peace and stability. For this purpose Vergil used for his personae (Dido, Aeneas) functional models of his time. Thus, in the readers' minds his personae could be associated with living persons. Vergil created mythical characters, setting them back more than a thousand years in time, combining myth and reality in order to interpret his own period. As Pease (1967, 24-28) pointed out, a number of scholars link Aeneas, Dido, and perhaps even the minor characters in the Aeneid with Augustus, Cleopatra, and their contemporaries. I will discuss the views of Pease more fully in section 4.2.5. It is likely that, when Vergil created the persona of Dido, he used the most unique and visible characteristics from his functional model without making Dido - the heroine of the first half of his epic - an identical copy of her model in each and every detail. My proposition is that Cleopatra served as the functional model for Dido and that the portrayal of Dido in turn reflects Vergil's appreciation of the Egyptian queen. The use of Cleopatra and Augustus as functional models for Dido and Aeneas respectively becomes the origin of associations with contemporary persons or events in his readers' minds. For example, when Aeneas followed his destiny and deserted Dido, the reader is reminded of Antony who - unlike Octavian - shirked his responsibility and stayed with Cleopatra. The Aeneid provided Vergil with an opportunity to deliver his commentary on the social and political situation of his time.

Virtually all scholars who identified a model for Dido, considered only the option of a literary model, and did not examine the possibility of a functional model. To my knowledge, it is only Otis $(1966,62-96)$ who hints at the latter. He $(1966,76)$ outlines Vergil's use of the literary model when he says:

Virgil in short has taken Apollonian, Homeric, and even tragic materials to form the structure of a very complex and very un-Apollonian and un-Homeric epic. His similes are clearly modelled on those of Apollonius and Homer but, unlike theirs, are integrated with the whole poem in virtue of their association with leitmotifs that recur at pivotal moments of the action.

145 See also Galinsky (1996, 229-231), who discusses a number of mythical women as possible literary models. 
What Otis $(1966,76)$ says about "their association with leitmotifs at pivotal moments" can be considered representing Vergil's second (functional) objective in addition to the literary. However, this is only my conjecture, as Otis does not further elaborate on this point and does not suggest the specific notion of the functional model.

Who are the favourite models in the secondary literature? Many women, generally mythical heroines and even goddesses, are paraded as possible models for Dido (Horsfall, 1995, 133-134; Muecke, 1983, 144 notes 43-50). One finds Hypsipyle, Medea, Helena, Calypso, Nausicaä, Cleopatra and many others. Horsfall $(1995,133)$ remarks: "In despair, attentive readers of Aen.4 are reduced to drawing up lengthy lists of Dido’s mythical and literary analogues.” In the case of Dido he (1995, 133-134) offers a useful classification by distinguishing between three categories of models: (i) "alleged allegorical comparisons, notably Cleopatra, (ii) Dido in Naevius, Varro, and Ateius Philologus, (iii) Homeric antecedents, female and male, and antecedents in Greek tragedy and Hellenistic poetry.” At the end of the fourth or the beginning of the fifth century A.D. at least one attentive reader of the fourth book of the Aeneid made his choice of a model. Macrobius wrote in his Saturnalia (Macr.5.17.4): adeo ut de Argonauticorum quarto, quorum scriptor est Apollonius, librum Aeneidos suae quartum totum paene formaverit, ad Didonem vel Aenean amatoriam incontinentiam Medeae circa Iasonem transferendo (Willis, 1963, 315) (Thus he has modelled his fourth Book of the Aeneid almost entirely on the fourth Book of the Argonautica of Apollonius by taking the story of Medea's passionate love for Jason and applying it to the loves of Dido and Aeneas) ${ }^{146}$. Knauer $(1979,209)$ states "Die Medea des Apollonios von Rhodos wie die des Euripides haben das Bild der Dido bestimmt ${ }^{147}$." Farron (1993, 61-62) holds the same view: "Vergil obviously modelled the Dido episode on that [love of Jason and Medea], as was observed, with exaggeration, by Servius, in his introduction to Book 4, and by Macrobius (Sat.5.17.4).” I differ from Farron's (1993, 62) view that "the Dido story is completely an episode. It has no effect on the Aeneid's plot or on Aeneas' moral and intellectual development." On the contrary, through Dido's episode Vergil makes Aeneas' destiny clear. In section 4.2.4, I will discuss Nelis' (2001) claim that Medea was the model for Dido. I will argue that Medea was probably one of the literary models for Dido, but that she was not Dido's functional model. Desmond (1994, 32), discussing "Virgil's Dido in the Historical Context," states that "Dido also functions as a figure for Cleopatra." However, the focus of Desmond is on the "feminine, sexualized, oriental threat to centralized Roman power" (1994, 32). I argue that Vergil offered a much more comprehensive view on the two queens (see also note 152 and section 4.2.3).

146 The translation is by Davies (1969, 359); reprinted with permission of Columbia University Press.

147 Medea of Apollonius Rhodos and of Euripides have determined the image of Dido. 
In the following section (4.2.2) the question whether Vergil used stories about a mythical Dido which may have existed before his time - Horsfall's second category will be considered.

\subsubsection{Dido: Was She A Historical Character? Early Myths}

Dido's history as described by Vergil was founded on the established tradition of his time, which was narrated by Timaios, a historian from Tauromenium, Sicily (ca.356260 B.C.), and perhaps by others whose works are no longer extant (Desmond, 1994, 24-27; Monti, 1981, 20-21). Other mythical stories about Dido circulated at the time, of which some will be discussed in this section ${ }^{148}$. Nowadays, there is general consensus - based on modern archaeological research - that there was an earlier Phoenician trade post on the site of old Carthage and that the city was founded by Elissa (Dido) of Tyros in 814 B.C. (Moscati, 1984, 38-47).

In Phoenicia's history, the beginning of the ninth century B.C. was of crucial importance. At that time the power of Assyria increased and the independence and freedom of the Phoenician cities diminished rapidly. The annals of the Assyrian king Assurnasirpal II (883-859 B.C.) say (Moscati, 1968, 15):

At that time I marched along the side of Mount Lebanon, and to the Great Sea [...]. The tribute of the kings of the seacoast, of the people of Tyre, Sidon, Byblos, etc [...] - silver, gold, lead copper [...], and ivory, and a nahiru, a creature of the sea, I received as tribute from them and they embraced my feet.

The Phoenician cities did not put up an armed resistance and gradually submitted themselves to Assyria. It is assumed that internal strife in some cities, the increasing pressure from Assyria, and the harshness of the Assyrian regime led in the ninth century B.C. to a growing emigration to other parts of the Mediterranean region. This also caused the departure of Elissa, the sister of king Pygmalion of Tyros, who was married to her uncle Acharbas (who in A.1.343 is called Sychaeus), and left the city after the assassination of her husband, together with a group of citizens from Tyros. The eldest source on these events is a fragment which originated from Timaios and was quoted in the Strategemata of Polyaenus (Jacoby, 1950, 624) ${ }^{149}$. The fragment says:

Timaios says that she, who in the Phoenician language is called Elissa and who was a sister of king Pygmalion of Tyros, is reported to have founded Carthage in Libya. When her husband was murdered by Pygmalion she put her possessions in ships and fled together with some citizens.

148 Timaios, Fragments in: Jacoby (1950, 624); See also: Horsfall (2007, 138-144); Pease (1967, 16).

149 Polyaenus lived in the second century A.D. 
After great suffering and after a long journey she arrived at Libya and was received friendly by the local people. After she had founded the afore-said city, and as she wanted to become queen of the Libyans, she was forced by the citizens to marry, but she resisted. She pretended to solemnize the ceremony which would free her from her vows, but she had a very high pyre erected near her palace, set this on fire, and threw herself from the building on the pyre.

The story in this fragment - Dido committing suicide to escape from a forced marriage - differs substantially from that in the Aeneid. Aeneas does not feature at all in the fragment. Noteworthy is of course that in about 300 B.C. Timaios assigned the founding of Carthage to Elissa of Tyros. Vergil may have used and perhaps modified a well-known mythical story about Dido, which has since been lost. This leads to the question of what and how much was known about Dido and the founding of Carthage in Vergil's time. Our knowledge about this is very limited due to the paucity of the extant sources about Dido from the time before Vergil.

Some fragments in which Dido is mentioned have survived. These are fragments of the Bellum Poenicum of Gnaeus Naevius, some of the Annales of Quintus Ennius, some texts in later commentaries of the fourth century A.D., such as those of Servius and Macrobius, and finally a fragment that is included in the Anthology of Planudes translated by Ausonius ${ }^{150}$. These later texts indicate that indeed more archaic stories about Dido existed which have been lost but which Vergil may have known. Whether he was guided by myths about Aeneas and Dido, which existed in his time, has given rise to much speculation in the secondary literature. I will discuss the most relevant texts.

First, in book 1 of the Bellum Poenicum, Naevius (ca.270-ca.200 B.C.) described the history before the First Punic War, in which he fought. Naevius went back to the flight of Anchises and Aeneas from Troy and he mentioned a great storm in which the Trojans found themselves. Dido, however, is never mentioned in the whole extant part of the Bellum Poenicum. Some modern authors believe that a number of fragments from the Bellum Poenicum 1 may refer to Dido, for example fragment 18, fragment 19 and fragment $20^{151}$. In addition, there exist a number of references of commentators of later centuries, which may suggest that Naevius mentioned Dido. In his commentary on A.4.9, Servius (Thilo \& Hagen, 1923, vol. I, 462) has handed down to us: cuius filiae fuerint Anna et Dido, Naevius dicit (Naevius said, that Anna and Dido were his daughters). At the beginning of the fifth century A.D., Macrobius (Macr.6.2.30-31) wrote that the first book of the Bellum Poenicum exercised great influence on Vergil (Willis, 1963, 365; see also Horsfall, 2001, 138-144). The passage says: Sunt alii loci plurimorum versuum quos Maro in opus suum cum paucorum immutatione verborum a veteribus transtulit. [...] in primo Aeneidos tempestas describitur, et Venus apud Iovem

150 Paton (1960, 248); the epigram about Dido that is cited here is by an anonymous author. 151 Horsfall (2007, 138-144); Hunink (2006b, 63-64). The indication of the fragments of the Bellum Poenicum is according to Morel, 1995. 
queritur de periculis filii, et Iuppiter eam de futurorum prosperitate solatur. hic locus totus sumptus a Naevio est ex primo libro belli Punici. (There are other places with many verses, which Vergil has transferred from former writers to his own work, with the change of a few words. In the first book of the Aeneid there is a description of a storm; Venus complains to Juppiter of the dangers for her son, and Juppiter comforts her showing her the success of the future children. The whole of this place is taken from Naevius, from the first Book of his Bellum Poenicum).

Second, two extant fragments from the Annales of Ennius, in which he related the history of Italia and Rome from the mythical beginning after the fall of Troy, may refer to Dido and the founding of Carthage. These are fragment inc.27 (verse 472) from Annales, liber 7: Poenos Sarra oriundos (Phoenicians [people of Carthage] descended from Sarra [Tyros]), and fragment 8.24 (verse 297) from Annales, liber 8, where Ennius writes about the Second Punic War and where he warns the Romans not to underestimate the people of Carthage. The text says: Poenos Didone oriundos (Phoenicians descended from Dido). These two fragments are found in books 7 and 8 of the Annales, but Dido cannot be found in the extant fragments of book 1, where Ennius writes about Aeneas' mythical journey to Italia and the founding of Rome and where her name is to be expected ${ }^{152}$.

Third, in Ausonius' translation from the Greek of the epigram in the Anthology of Planudes, it is said of Dido that she never met Aeneas and never lived in Libya at the time of the destruction of Troy, but that she committed suicide by the sword in order to escape a forced marriage to Iarbas. She asks the Muses why they made Vergil slander her honour (Paton, 1960, 248-249; part 4, epigram 151). This epigram is most likely from an anonymous author from the Hellenistic era, and may indicate that a story about Dido and Aeneas was known before Ausonius' time. But the epigram also suggests that it was considered an unlikely story.

Fourth, Servius' commentary on A.4.682, exstinxti te meque, soror (you have destroyed yourself and me, sister) says: Varro ait non Didonem, sed Annam amore Aeneae impulsam se supra rogum interemisse (Varro said that not Dido but Anna, impelled by her love for Aeneas, took her own life on the pyre) (Thilo \& Hagen, 1923, vol. I, 580). This text turns the whole Aeneid upside down, with either both sisters taking their lives or Dido living on after Aeneas' departure.

Finally, Macrobius (Saturnalia 5.17.5-6) writes that Vergil has portrayed Dido's passion so beautifully that quam falsam novit universitas, per tot tamen saecula

152 Fragment inc.27 in Hunink (2006a, 82); Skutsch (1985, 114); Warmington (1988, 84). Fragment 8.24 in Hunink (2006a, 92); Skutsch (1985, 95); Warmington (1988, 98). Hunink (2006a, 73-74) states that fragment inc.18 refers also to Dido, namely to her arrival in Africa. The problem is here that Dido is not mentioned by name and that this text can also refer to others, for instance to Punic soldiers in general. The indication of the fragments of the Annales in Hunink's and my text is according to Skutsch, 1985. 
speciem veritatis obtineat (what everybody knows to be incorrect, still has been viewed as true during so many years). Everyone knew of the chastity of the queen, but chose to believe the poet's version ( Willis, 1963, 315. See also Davies, 1969, 359).

In sum, Timaios' text about Dido and the anonymous epigram in the Anthology of Planudes are strikingly similar. Both texts say that Dido took her own life to avoid a forced marriage. In Timaios' text, Aeneas is not mentioned at all, and the author of the epigram even explicitly denies any relationship with Aeneas. Thus, the evidence is very conflicting and it appears that it is no longer possible to trace whether Vergil used stories about a mythical Dido - written or oral - which may have existed before his time, and which he adapted and turned into the Dido we know from the Aeneid. Horsfall $(2007,142)$ says the following about this: "But are we in a position to say anything about the function and character of Dido in the BP [Bellum Poenicum]? Or about the influence of Naevius' Dido on Virgil's? Any reconstruction is a mere house of cards." 153 This "house of cards" applies not only to the Dido in the Bellum Poenicum but also to the picture of her which could arise from other extant mythical sources. Nowadays one can only conclude with any form of certainty that a mythical Dido from Carthage was known before Vergil's time and that it is likely that someone said that a Dido committed suicide on a pyre. Vergil's Dido, however, is a "complete" woman to whom he attributed many features. Did Vergil perhaps connect the arrival of a mythical Aeneas, which Naevius had mentioned, with a semi-historical Dido and did he construct a new myth from these facts? Anyway, the answer cannot be found in our extant sources and it will remain unresolved whether Vergil used earlier myths. It is likely that Vergil's Dido and Aeneas are fiction.

\subsubsection{Dido In The Aeneid}

How does Dido come across in the Aeneid? Who is Dido, in her public appearances and as a private person? To find plausible answers, a number of relevant passages from books 1 and 4 of the Aeneid will be briefly discussed ${ }^{154}$.

In A.1.338-368, Vergil relates that Dido left Tyros together with her supporters to establish a new kingdom and to rule there as their queen. $A .1 .360$ reads: his commota fugam Dido sociosque parabat (moved by this, Dido prepared her flight and her company). In A.1.364, the poet says: dux femina facti (a woman was the leader of

153 Horsfall (2007, 138-144). It is noteworthy that Horsfall (2007, 144) also states: "the influence of Naevius' Dido on Virgil's in character and function was, I suspect, vastly greater than can now be plausibly guessed, let alone proved."

154 Quinn (1963, 48-49). Quinn discusses extensively Dido's and Aeneas' love and the inevitability of “Dido’s downfall.” See also: Cairns (1989, 136-145); Horsfall (1995, 123-134); Muecke (1983, 134-155); Rudd (1976, 32-53). 
the venture). The last three words express that it was very unusual that a woman is the leader of the expedition. In book 1 this point is again emphasized when Aeneas cautiously enters Carthage and sees Dido at work there. In A.1.507-508, iura dabat legesque uiris, operumque laborem/partibus aequabat iustis aut sorte trahebat (she administered justice and made laws for her people, and she settled their tasks in fair portions or assigned these by lot), Vergil portrays Dido as a woman who acts to all intents and purposes as queen and who uses her regal powers to the benefit of her people $\mathrm{e}^{155}$. In several other passages in book 1 Dido is portrayed as a good queen: she is forma pulcherrima (A.1.496, a great beauty), she is likened to Diana and has divine qualities (A.1.499), and goes ad templum (A.1.496) with royal piety. When a party of stranded Trojans is allowed to address her, Dido declares that the Trojans are very welcome. She invites them to stay and to build Carthage with her and her people. She emphatically includes Aeneas. Vergil suggests here that she is considering establishing a new dynasty with Aeneas if he were to arrive in Carthage. In A.1.573-574, Dido says: urbem quam statuo, uestra est; subducite nauis; Tros Tyriusque mihi nullo discrimine agetur (The city I founded is yours; haul up your ships on land; I will not discriminate between Trojans and Tyrians).

At the end of book 1 (A.1.748-749) things develop as the reader expects. Dido is struck by Amor: nec non et uario noctem sermone trahebat/infelix Dido longumque bibebat amorem (And unhappy Dido also spun out the night with varied talk and long she drank the cup of love). It is often held that Aeneas courted Dido and that she reluctantly consented. Dido certainly had her doubts, as is made clear in book 4 when she discusses her new love with her sister Anna. However, Dido also took initiatives herself as one reads in book 4. She takes the lead and decides to win over Aeneas when she shows him round the city (A.4.74-75). In A.4.129-159, Dido and her suite and Aeneas with his Trojans go hunting. A sudden thunderstorm forces them to take shelter and Dido and Aeneas find themselves in the same cave: speluncam Dido dux et Troianus eandem/deueniunt (Dido and the Trojan chief came to the same cave) (A.4.165-166). Juno and Venus consented to the marriage, as we read in A.4.126-127: conubio iungam stabili propriamque dicabo./hic hymenaeus erit (I [Juno] will link them in a lasting marriage and I will pronounce her his own. This will be their wedding). When the queen and Aeneas leave the cave Vergil tells us (A.4.170-171): neque enim

155 Syed does not have such a positive perception of Dido. Comparing Dido and Cleopatra, she $(2005,184)$ asserts that in the Aeneid "there is a series of literary allusions that link Dido to threatening images of female rule.” As evidence she discusses among other things A.1.490-504 (Syed, 2005, 184-185) and A.1.507 (Syed, 2005, 185-186). I do not concur with her view that Vergil's representation of Dido's (and Cleopatra's) rule is expressed "in terms that reassert well established attitudes about women's roles in ancient societies" (Syed, 2005, 186), seeing “Dido and Cleopatra associated with the discourse of orientalism. Female rule and orientalism intersect in these two figures to create powerful images of the Other against which Romanness is defined" (Syed, 2005, 186). Vergil held Cleopatra (and Dido) in high regard and saw them as a new version of what female rule could be like. 
specie famaue mouetur/nec iam furtiuum Dido meditatur amorem (For no longer Dido is guided by appearance or reputation, no more does she think of a secret love). In A.4.54-173, Dido is a woman who is totally engrossed in her love for Aeneas and who creates opportunities to share her love with him.

With Aeneas hanging about in Carthage, Iuppiter decides that he cannot any longer condone Aeneas' neglect of his duty, and the chief god sends Mercury to dispatch Aeneas to Italia at once. Dido is aware that Aeneas is going to leave her and she reproaches him for his departure. Dido's anger and distress are not just a result of Aeneas' choice to follow his own path and to reject her love. Something else is the matter. In A.4.327-330 Dido says:

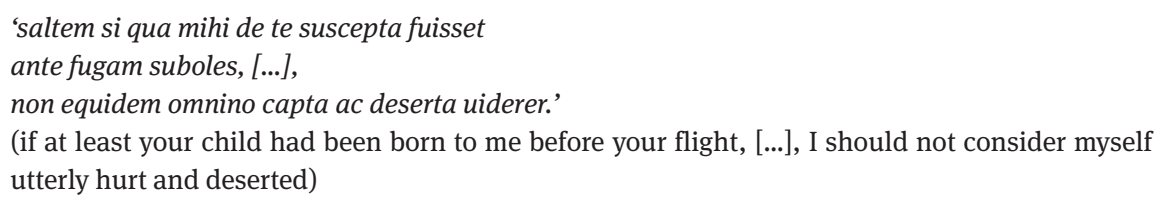

This is not just an expression of Dido's distress due to the loss of Aeneas' love. In this passage the childless Dido also displays her frustration over her failure to start a new dynasty with him. Aeneas leaves for Italia and Dido takes her life on the pyre. They will meet once more when Aeneas visits the underworld.

Although, in general, Vergil writes "sympathetically" about Dido, the poet does not hold unreserved affection for her. When the story develops Vergil also reveals Dido's negative traits. Dido acts without self-control and dignity when she begins to suspect Aeneas' departure (A.4.300-303); such fury does not befit a good queen. This is repeated a few moments later when she tells Aeneas what she thinks of him (A.4.365-392, esp. at 4.376: furiis incensa, set on fire by fury ${ }^{156}$. Vergil also shows Dido in an unfavourable light in A.4.584-629. She sees that Aeneas' fleet is preparing to depart and for obvious reasons this arouses a deep anger within her. However, she does not voice her anger but instead is enveloped in a fierce hatred. Again, Vergil does not portray her as a queen who acts in a composed manner, as a good queen should. Although the poet - and his audience - may have felt compassion with Dido's despair, he probably wanted to point out that the responsibilities of her high office should take precedence over her private grief. Shortly before uttering her curse, Dido had wished a little baby brother for Ascanius (A.4.328-329) (cf. Rudd, 1976, 47-48). I do not concur with Desmond (1994, 30), who argues that Dido's change from a "good" to a "bad" queen occurs because "Dido's activities as a lover explicitly compromise her status as 'good king.'” In my opinion, Vergil portrays her genuine love for Aeneas, which she connects with her wish for a child to establish a new dynasty. This is very much

156 See also section 4.1.1, where I discussed furiis accensus being applied to Aeneas' killing of Turnus at the final of the epic, referring to Aeneas' loss of self-control not befitting a good king. 
part of Vergil's depiction of Dido as a responsible ruler. Her “activities as a lover" are no aberration, but her loss of self-control, when her plans are frustrated, is. The lines A.4.600-603 from her long tirade show the other side of Dido:

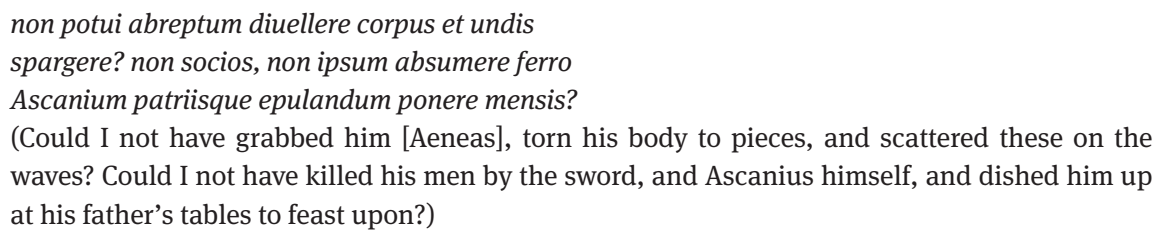

Her anger is not just directed against Aeneas: a few lines later she prays for an ongoing hostility between her people and Aeneas' descendants (A.4.622-626):

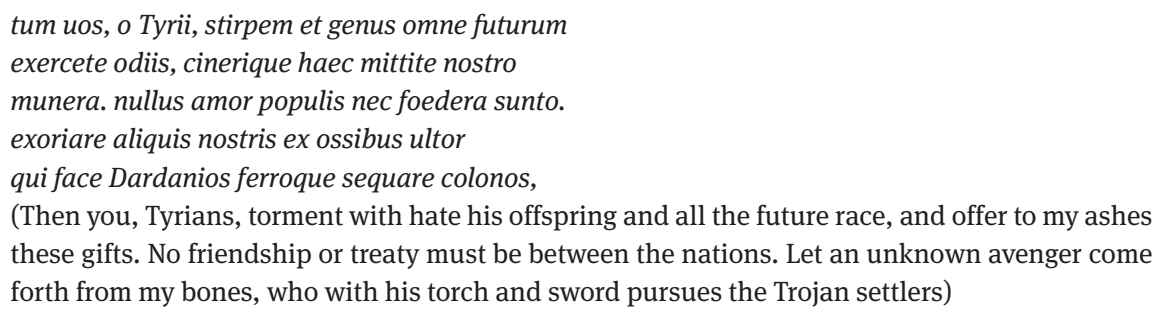

The above passage is a prophecy by Dido, in which she foretells that Aeneas will experience many hardships and struggles and "legend told that his reign was brief and that he met an unnatural death at the river Numicius, his body disappearing and so not given burial" (Goold, 2006, 464-465 note 6). The last two lines (exoriare.... colonos) refer not only to Aeneas' fate, but can also be interpreted as referring to the Punic wars and to Hannibal (aliquis ultor) and as an allusion to Vergil's own days.

Vergil's portrayal of Dido is subtle and shaded, showing her good and bad sides. The picture of her is that of an independent queen, superior to many men, a leader of her people, who makes decisions about the organization of the city. She possesses the ambition to establish a new empire. Dido shows courage and physical strength in her public role, and she has an elevated social position. She is the leader of the Carthaginian society, at the top of the elite. On a personal level, she openly embraces her love for a stranger and takes initiatives in her relationship with him. Initially, in her new passion she does not lose sight of her public responsibilities as she regards her new love as an opportunity to safeguard the future of her dynasty. However, the poet is not unreservedly positive about Dido. When the story develops one sees Dido's negative traits. Vergil portrays her also without self-control and dignity. Dido did not fit the model of the female member of the Roman elite of Vergil's time. Although from the second century B.C. onwards women of the Roman elite moved about more freely, they remained dependent on their husbands, their fathers-in-law or other 
male members of their family. Dido was not the ideal wife and mother. She stood out high above the few women who had achieved some elevated station in public life. Compared to those women she was unique $\mathrm{e}^{157}$.

In this context it is also important to note the way Vergil portrays Lavinia, as Yvan Nadeau pointed out to me: "What does the portrait of Lavinia have to tell us about Augustan politics? She is the 'female interest' of the second half of the Aeneid as Dido is the 'female interest' of the first half." ${ }^{158}$ In A.6.763-765, Lavinia is mentioned for the first time in Anchises' prophecy: Siluius, Albanum nomen, tua postuma proles,/ quem tibi longaeuo serum Lauinia coniunx/educet siluis (Silvius, Alban by name, your last-born son, whom your wife Lavinia late in your life shall bear in the woods). This is rather typical of Lavinia's portrait in the Aeneid, as she is more often talked about than she herself speaks. In A.7.52-106 we learn more about her, the dutiful and selfeffacing daughter of king Latinus, who is iam matura uiro, iam plenis nubilis annis (she was now ripe for a husband, and marriageable). Turnus woos her and this match is strongly supported by Amata, Latinus' wife. But forceful portents tell the king that externi uenient generi (sons-in-law shall come from foreign lands) and that their offspring will rule the world (lines 96-101). Iuno resists vehemently Lavinia's fate in marrying Aeneas and we read the foreboding of the struggle between the latter and Turnus in A.7.313-322: in line 321 a parallel is drawn between Paris and Aeneas. Thus, Aeneas is twice accused of landing in a foreign land and stealing women who were promised to other men: blamed by Iarbas in the case of Dido and by Iuno with respect to Lavinia. The parallel with Paris also implies a parallel between Helen and Lavinia as being the causes of war ${ }^{159}$. In A.7.318-322 we read:

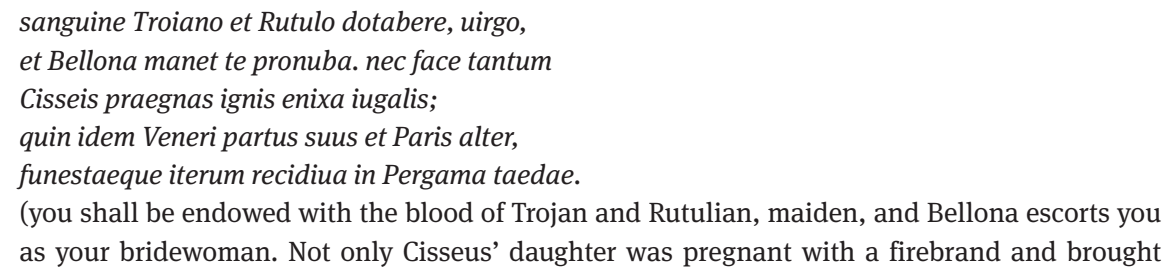

157 Vergil may have been aware of the position of women in Cleopatra's Ptolemaic-Egyptian society, which differed considerably from contemporary Rome: Fantham, Foley, \& Kampen, et al. (1994, 140168); Pomeroy (1984, 171-173). For general discussions of women's role and position, see: Fantham, Foley, \& Kampen, et al. (1994, 260-265, 271-274, 294-329) (although in the latter section the emphasis is on women, family and sexuality, it presents a good summary of women's position in general); Oliensis (2007, 221-234); Pomeroy (1984, 115-119); Treggiari (2005, 130-147).

158 Nadeau, 2011, private communication. See also Williams (2006b, 170-171, 190-192); Woodworth (1930, 175-194).

159 Bellona is the sister of Mars. Cisseus' daughter is Hecuba, who dreamed that she was pregnant with a firebrand before giving birth to Paris. Nadeau (2010a, 221-222); Williams (2006b, 190-191). Vergil draws the parallel between Paris and Aeneas at an earlier occasion in A.4.215, when Iarbas calls Aeneas ille Paris (that Paris) (Williams, 2006a, 350). 
forth a son [whose wedding caused] a blaze; no, Venus is the same in her own son, a second Paris, and deadly torches will come once more to rebuilt Troy)

Iuno lets the Fury Allecto strengthen Amata's resolve that Lavinia marry Turnus, and the queen hides her daughter in the woods: Lavinia only reappears in A.11.479. The matter is eventually settled after Aeneas has struck down Turnus in the duel, when the latter says: tua est Lauinia coniunx (Lavinia is your wife) (A.12.937). Lavinia is portrayed as the dutiful, demure girl, the ideal Roman maiden, subordinating herself to her father and to her duty. The difference between Dido and Lavinia is of course that Dido and Aeneas were passionately in love, while Aeneas is not in love with Lavinia (Woodworth, 1930, 185-187). Vergil makes this clear in an indirect way in A.12.192-194, when referring twice to Latinus as Aeneas' socer (father-in-law), and only mentioning Lavinia in line 194 within the context of the dynastic and political settlements between Aeneas and Latinus. Vergil makes the point that Aeneas did his duty both when he left Dido and again when he married Lavinia in a mariage de raison. Lavinia accepted this arrangement, because she had no choice, as was to be expected of a daughter. Similarly, Octavian did his duty marrying Livia Drusilla in 38 B.C., although this marriage was blemished by Livia being a wife and mother. Thus, the Aeneas/Paris parallel can be interpreted as a critical allusive reference to Octavian also stealing other people's women. Vergil's portrayal is in a sense a forerunner of Augustus' Leges Iuliae (Woodworth, 1930, 187). The passage about Lavinia (A.7.52-106) can also be interpreted as Vergil using Augustus as a functional model for Aeneas, and thus referring back to another aspect of the contemporary political situation. The parallel is that Octavian did his duty as a leader taking responsibility for restoring stability in Rome: this was in sharp contrast to Mark Antony, who enjoyed himself in a consuming love affair with Cleopatra. Woodworth (1930,188-194) identified three relevant parallels between Lavinia/Aeneas and Livia/Augustus, which I will examine in more detail in section 4.2.6, where I discuss the possibility of Augustus being the functional model for Aeneas.

The contrast between Vergil's portrayal of Dido on the one hand and of Lavinia on the other is also significant for another theme, namely the poet's opinion about the role of women in society. Vergil held a much more "liberal" view on this than the great majority of his contemporaries ${ }^{160}$. This can be deduced from his choice of Cleopatra as a functional model for Dido - which I shall argue below - and the unique features that he gave his Dido and which he must have recognised in Cleopatra, such as for example their queenship, independence, role in battle and intelligence. This suggests that Vergil did not consider Cleopatra an evil woman, but that he approved

160 For the role of women in Roman society see Fantham, Foley, \& Kampen, et al. (1994, 260-265, 271-274, 294-329); Oliensis (2007, 221-234); Treggiari (2005, 130-147); Wyke (2004, 98-140). For the position of Cleopatra see Fantham, Foley, \& Kampen, et al. (1994, 136-139); Kleiner, 2005b; Pomeroy (1984, 3-40, esp. 24-28). See further for the life of Cleopatra: Schäfer, 2006; Volkmann, 1958. 
of her positive qualities. He presumably also knew of the much more prominent role of women in Ptolemaic society and I guess that by referring to Cleopatra in his portrait of Dido he showed his approval, and perhaps even his admiration of the extension of women's activities in more domains than those of the traditional Greek or Roman women $^{161}$. His rather flat depiction of Lavinia, the paradigm of the dutiful Roman woman is in strong contrast with this and it is evident that Vergil felt more attracted to Dido than to Lavinia, or to Cleopatra than to the average Roman matron ${ }^{162}$.

\subsubsection{Models For Dido}

Above (section 4.2.2), I concluded that it will remain unresolved whether Vergil used earlier myths as a model for Dido, Horsfall's (1995, 133-134) second category. In this section I will explore whether Vergil may have used a model from Horsfall's third category ("Homeric antecedents, female and male, and antecedents in Greek tragedy and Hellenistic poetry"). In examining Vergil's use of mythical or literary antecedent, Dido's unique and special features, namely her public actions as a queen, her independence and her leadership, are significant. Although Vergil could have used several models for different aspects of Dido's persona, and although it may be feasible that he did this for some features, it is not likely that he did so for the unique character and status of Dido. None of the mythical women, whom he may have used, founded an empire, built a city, or was the independent queen of her people, the commander of soldiers or a lawgiver. Although some of these characteristics are indeed assigned to the queens of the Amazons or Hypsipyle, they did not achieve the full measure of queenship as Dido did.

Other mythical women are also inappropriate as models, as can be seen from a comparison between Dido on the one hand and, for example, Andromache and Medea on the other. These two women have been chosen because, on the one hand, they exemplify the female role and position in their own time and, on the other their characters and actions can be adequately constructed from the extant epic literature. In the sixth book of the Iliad Andromache is portrayed as a woman who obviously loves her husband (Iliad.6.407-613), and to whom she is subservient. Her role is within

161 Fantham, Foley, \& Kampen, et al. (1994, 136-168) and Pomeroy (1984, 41-51) analyse the role of women of the Ptolemaic nobility in more detail.

162 Indications of Vergil's positive attitude towards women can also be found in the Eclogues. In Ecl.1, Amaryllis enables Tityrus to purchase his freedom. In Ecl.8, Nysa is not given away in marriage to a shepherd, but to a newcomer who offers her a better future instead. Similarly, in Ecl.10, Lycoris, Gallus' love, ran away with a soldier. Vergil does not disapprove of these women, who determined their own future. The woman in Alphesiboeus' song in Ecl.8 loses her husband to a girl who does not belong to her world. Vergil gives the woman her own independent view on the events which have overturned her life in the countryside. See also the relevant discussions in sections 3.1 and 5.1 . 
the family as a wife and mother. At home she is the manager. When she ventures beyond domestic affairs, she is curtly rebuked by her husband Hector, as in the scene in which she offers him some sound military advice (Iliad.6.484-492). However, this is something she accepts. For her it is not possible to conceive a life without her husband as protector and bread-winner. She is thus very well in keeping with the archetype of the female member of elite within Homeric society (Loraux, 1981, 75-117; Fantham, Foley, \& Kampen, et al., 1994, 33).

Medea in Apollonius Rhodius' Argonautica is a different story. Medea develops, from a girl with a consuming passion for the stranger Iason, into a woman. She struggles with this love and its consequences. She is portrayed as somebody who can analyze and articulate her feelings: a woman with brains and with a heart. She shows initiative, stands up for her own interests, and takes her own decisions, such as leaving her parental home in Colchis in spite of her family ties. In the end she stands up against Iason, the hero, and considers herself equal to him. Medea is much more a woman of the world than Andromache and in her case we do not hear anything about domestic chores. Apollonius was very familiar with Alexandrian high society in the third century B.C.. He was born in the city and lived and worked there for many years as Librarian of the Museum and tutor to Ptolemy III. When he wrote his epic in the middle of the third century B.C., the first signs of a broadening role for women were becoming apparent. Although it is feasible that Apollonius portrayed Medea with the position of the originally Greek female elite of Alexandria of those days in mind, she did not reach the elevated status of a Hellenistic queen. This was reserved for the female members of the Ptolemaic dynasty (Pomeroy, 1984, 41-82). Nelis (2001) argues that Medea as portrayed by Apollonius in the Argonautica was the model for Dido. Nelis has indeed demonstrated that there are significant references to Apollonius' Medea, and she is probably one of Dido's literary models. Nelis $(2001,85)$ refers briefly to “Dido's queenly status” when he writes: "Dido may be a lover in a similar mould [like Medea]. In another sense, however, the two women are quite different. Dido, when she is compared to Diana, is a queen intent on the building and organisation of a city, and her public functions are her main concern.” Although Nelis acknowledges Dido's public status, he does not suggest a second (functional) model for Dido. It is unlikely that Medea was Dido's functional model as Medea did not posses Dido's unique key features: a queen who performed all the duties which queenship demanded. Nelis $(2001,184)$ concludes: "The sheer weight of the evidence set out in the two preceding chapters suggests that the Medea of Apollonius is the central model for the creation of Vergil's Dido." Nelis has indeed demonstrated that there is much literary continuity. In my opinion, however, the functional model is "central."

The differences between Dido, as portrayed in Vergil's Aeneid, on the one hand, and her mythical sisters Andromache and Medea on the other are very clear. Dido is a queen with all the ensuing characteristics, and Andromache and Medea are royal princesses and wives. In the cases of all three mythical women their decisions in matters of love have an important bearing upon the course of their lives, but with 
some crucial differences. Andromache is an example of self-effacing conjugal love. Medea revenges the rejection by Iason but her vengeance remains within the limits of their personal relationship, as it is played out on their sons. Dido however experiences her love for Aeneas as a woman with a public duty and sees his departure not just as a personal rejection. The decisive issue for her is the loss of authority she suffers. Her suicide is in a sense also an abdication from the throne. Dido's persona is unique for the time in which Vergil created her, while Andromache and Medea occupy positions which one would have expected women to hold in the societies of either Homer's or Apollonius' times.

\subsubsection{Cleopatra And Dido Compared}

I concluded before that it is impossible to know whether Vergil used existing myths about Dido. Neither does Horsfall's third category (models from Greek epic, tragedy or Hellenistic poetry) seem to fit. Horsfall's (1995, 133-134) first category, "the alleged allegorical comparisons," seems to be promising. In this section I will argue that Vergil had one particular woman in mind whose characteristics he applied when he created the public and private persona of Dido. If - as I believe - he wanted to emphasize the unique character of Dido in her public role, he was most likely to choose a model whose public appearance could be recognized by every reader, immediately and without reserve. Although some scholars mentioned similarities between Dido and Cleopatra, it was only Pease (1967, 24-25) who offered evidence of similarities between the two women, for example the point that "both women are queens," that both had a relation to an "important figure in Trojan-Roman history," and that both committed suicide. However, Pease is not wholly clear when he simply writes that Dido was a queen. He (1967, 24, note 163) asserts that "emphasis upon Dido's queenly dignity appears constantly [in the Aeneid]," and later in his commentary on the opening line of book 4 (At regina) he (1967, 83-84) says that "Virgil intended to emphasize throughout the queenliness of Dido, as Horace (C.1, 37, 30-32) did that of Cleopatra.” Pease's choice of words - queenly dignity, queenliness - may imply that he considered Dido a woman who was as decorous and distinguished as a queen, but that he did not attribute to her the full royal status. He also does not suggest that Cleopatra was the functional model for Dido, as I do. Pease $(1967,27)$ holds a position in the middle when he says: "While, then, the figure of Cleopatra seems to have furnished some details for the picture of Dido, we should beware of pressing analogies where they may not exist," and (1967, 28) "If Dido is designed to suggest to some extent the figure of Cleopatra [...]." Pease $(1967,26)$ also points to some differences, for example the fact that Cleopatra rules a decadent society, while Dido is a pioneer, that they were of Aryan and Semitic descent respectively, and that Cleopatra "is bent upon her own licentious pleasures, while Dido is not only capable of great devotion to the memory of her dead husband but is desirous of establishing the Punic throne with a fixed succession” (Pease, 1967,26). 
Other scholars also noticed parallels between Dido and Cleopatra. Quinn (1963a, 35) and Cairns discuss these only within the context of Dido's love for Aeneas and the latter's desertion of the queen. Cairns $(1989,57)$ refers to the "destruction through 'love"” of Antony and Cleopatra and states: "It is well understood that Virgil to some extent modelled Dido upon Cleopatra.” Desmond (1994, 32) says: "Dido also functions as a figure for Cleopatra" (sic). All three scholars refer to Pease. Horsfall (1995, 133-134), suggesting his first category of analogues for Dido, namely "alleged allegorical comparisons, notably Cleopatra" also associates this with the tragedy of Dido's and Aeneas' love, their guilt and blame. Horsfall refers to Pease and Cairns, and to La Penna $(1985,54)$; the latter focused on Fama's gossip of both Aeneas' and Dido's care-free passion (A.4.189-197), and on Mercury's reproach to Aeneas for neglecting his duties $(A .4 .259-278)$. Galinsky $(2003,17)$ summarizes his essay as follows: “There are considerable affinities between Horace's portrayal of Cleopatra (Carm.1.37) and Virgil's of Dido. They involve verbal echoes, theme, treatment and especially tragic problemisation. [...]. Horace's Cleopatra, rather than the real Cleopatra, is one of the many models for Virgil's Dido." Syed's approach differs considerably. She (2005, 184-193) argues the specific proposition that Vergil's objective in the Aeneid was to (re)define Roman identity. Comparing Dido and Cleopatra, she states that Vergil did this by "projecting Cleopatra's gendered and ethnic otherness ['for the Romans of the Augustan period'] on Dido" (Syed 2005, 192), thus allowing the poet "to define Roman identity in the Aeneid not so much against the backdrop of the civil wars but by gesturing toward Rome's conflict with Carthage." Hardie (2006, 25-41) focuses on the erotic bond between Dido and Aeneas, and examines the consequences of their putative incestuous brothersister relationship in the Aeneid. He $(2006,28)$ argues that this relationship reflects contemporary Roman political invective which "in the 30s B.C. was directed against an alien royal household, the Ptolemaic dynasty of Alexandria [of Cleopatra and her brother-husbands]." To sum up, some scholars quoted have a very specific focus (for instance Syed, 2005; Hardie, 2006), while others recognize only a similarity to some extent between the two women.

I suggest that Cleopatra was Vergil's functional model for Dido for the purpose of giving his views on major contemporary political issues. The functional model implies that many passages in which the poet writes about the person of Dido can be seen as references to Cleopatra. When Vergil wrote the Aeneid he was living and working close to the centre of power. Vergil's position near Augustus would have made him highly aware of political developments and most likely he was also well informed about the political and social events of the fifteen-year period preceding the time when he started writing the Aeneid. It would not be surprising therefore, that he had a clear picture of Cleopatra in mind.

Above, the most relevant passages about Dido in the Aeneid have been analyzed, and a summary of Vergil's portrayal of Dido has been presented. Comparing Dido and Cleopatra, striking analogies both in public and in personal appearance become 
visible. In their public roles both were unique. The mythical Dido, queen of Carthage, held a position in her virtual society that was exceptional for a woman. Equally, the position of the historical Cleopatra was in general unattainable for women at the close of that age. Dido and Cleopatra were both independent sovereigns: they enacted law, administered justice and commanded their troops. They ruled kingdoms on the southern coasts of the Mediterranean, and both came to power after conflicts and strife within their families. Mythical Dido was a threat to Rome for two reasons. Firstly, Rome would not have been founded if she had managed to tempt Aeneas to stay with her, and secondly Dido built Carthage, a future threat to Rome. Cleopatra formed an actual danger to Rome and in the eyes of her Roman contemporaries she was a fundamental player at an important junction in Rome's history. The continuity of their dynasties was a prime issue for both of them, as much for Dido in her relation to Aeneas as for Cleopatra in her "marriage" with Antony. Both women saw great opportunities to build a powerful empire with their new partners.

There are also several parallels with respect to their personalities. Both women were intelligent and communicative. Cleopatra was attractive, but not especially beautiful, while Dido is described as a great beauty. They knew how to charm men, with Cleopatra as the clear champion in this respect. Both felt and behaved as equal partners of their lovers: in the case of Cleopatra this developed into a dominant position over Antony, while the relation between Dido and Aeneas was too short-lived to witness any profound development. Both women committed suicide in the prime of their lives. They acted out of frustration that their designs had failed, and they refused to subordinate themselves to their male opponents: Dido felt betrayed by Aeneas and Cleopatra had lost both her empire and Antony, and did not want to subject herself to Octavian.

\subsubsection{Augustus And Aeneas Compared}

One of Vergil's objectives in writing the Aeneid was to give his views on contemporary political issues. To this end, he used - among other things - Cleopatra as a functional model for Dido. His readers could recognise in Dido's persona and in her actions similarities with Cleopatra and thus take cognizance of the poet's views on Cleopatra. If the argument that Vergil used a functional model for Dido is accepted, the question arises whether he used a similar design for Aeneas. There are two arguments for this point of view. First, if Vergil wished to give his commentary on the political issues at the end of the first century B.C., it is unlikely that he would have done this by using a (functional) model for Dido but not for Aeneas. Second, in the Aeneid much is double-sided, using Tarrant's $(2012,27)$ terminology. Why not a duality Aeneas/Dido and Augustus/Cleopatra?

Several scholars have already identified that there are similarities between the persona of Aeneas and the real Augustus. Without attempting to be complete, I will 
briefly consider the views of Woodworth (1930), Cairns (1989), Powell (2004), Nadeau (2007, 2009, 2010), Tarrant (2000, 2012), and others.

Woodworth (1930, 188-194) called attention to three relevant parallels between Lavinia/Aeneas and Livia/Augustus: (1) Although Lavinia was not married, as Livia was, she was betrothed to Turnus. In both cases the welfare of the state demanded a different marriage for the women than was originally foreseen or was the case. (2) Aeneas, who after all is a poor newcomer in Italia "is to found his destined race by a union with the royal blood of the native stock" (Woodworth, 1930, 192). Similarly, Augustus was a parvenu for whom a marriage in Roman aristocracy would be very advantageous. (3) The expected result of the union of Lavinia and Aeneas is male offspring, which happens with the birth of Silvius, and this "corresponds to the unfulfilled but long-cherished hope of Augustus to beget an heir and found a dynasty" (Woodworth, 1930, 193) ${ }^{163}$. To my mind, this last parallel is the most significant as it again shows (in A.7.96-106) Vergil advocating a hereditary kingship, which he has done consistently throughout his work even before the Aeneid in Ecl.4 and in G.4.

Nadeau (2004, 255; 2007, 94-98; 2009, 35-42; 2010a, 230-231) also hints at the notion of Augustus as a functional model for Aeneas. Although he does not use the words "literary or functional model," through his detailed examination of the intertextuality between the Aeneid on the one hand and the Iliad and Odyssey on the other, he confirms Vergil's debt to Homer. Nadeau gives this literary inspiration an additional meaning, showing that much of what Aeneas experiences in his mythical pursuits runs parallel to important events in Octavian/Augustus' life. Therefore, the question is what came first. Did Octavian re-act Aeneas, which is very unlikely, or did Vergil choose events or traits of Octavian and shaped Aeneas out of these? The latter seems more likely. I will only briefly indicate some of the similarities that Nadeau describes and I refer the reader to his work for the details. The most notable examples are Aeneas' problems in the waters around Sicily (A.6.162-174), which can be interpreted as a reference to Octavian's struggle with Sextus Pompeius. Nadeau (2007, 94) also interprets the passage in A.3.209-267 as referring to Sextus Pompeius "who caused famine in Rome, causing disturbances there, before he was defeated by the fleet newly-trained and equipped by Agrippa." Contrary to Nadeau, I think it more likely that this passage refers to the more general struggle before Octavian established his reign, because: in the prophecy of doom by the Harpy Celaeno (lines 245-257), the emphasis is on the war which Aeneas/Octavian has to fight (lines 245-249) and not on hunger (lines 255-257). My interpretation is supported by Williams (2006a, 286) who states that in this passage "we see the Trojans again as exiles wandering in a wilderness of sea, very far from their promised home." Nadeau (2007, 97 and 2009, 35) suggests that the pietate grauem ac meritis [...] uirum (a man great in his sense of duty and great in his merits) in A.1.148-153 can be identified as fifth-century B.C.

163 My emphasis. 
Menenius Agrippa (see also Morwood, 1998, 195-198) and is thus an allusion to M. Vipsanius Agrippa, the friend of Octavian, and to his victory over Sextus Pompeius. In my opinion, the identification of Menenius Agrippa is rather speculative and I prefer to interpret A.1.151 as referring to any man who, in the words of Morwood (1998, 197), has the personal authority as "tamer of mob violence", and not necessarily a historical person. A further example given by Nadeau is the last stage of Aeneas' visit to Hades to reconcile with his opponents (A.6.854-886) which is connected to the death of Marcellus. Vergil mentions the Mausoleum of Augustus (built in 27 B.C.), and links a gloomy prediction for Aeneas with a gloomy prediction for Octavian. Nadeau (2004, 105-120, esp. at 120, and 255) thinks of the plot by Caepio and Murena in 23/22 B.C.. I discussed this passage in section 4.1.1, about references to Augustus, and I suggested there that Vergil is referring to Augustus' abortive efforts to establish a dynastic kingship. In addition, Nadeau mentions, among other things, the passage on Aeneas' wounding and recovery with the aid of Venus (A.12.383-429). I am sympathetic to Nadeau's $(2004,255)$ statement that the passage has a "sense of foreboding" of doom, relating to "Augustus' nearly-fatal illness of the same year [23 B.C.] - the which illness is symbolized, as we have seen, by the arrow-wound which nearly proves fatal to Aeneas - a matter we [Nadeau] studied in Chapter 3 [of his book].” The passage can indeed be interpreted as a functional reference to Augustus' illness and the fragility of the young Principate.

A third view is that of Tarrant (2012, 24), who argues that:

although Aeneas is an independent character and not an allegorical substitute for Augustus, the connections between the two are so strong that the view taken of one must inevitably colour one's view of the other; as Richard Thomas has written, 'ambivalence about Aeneas and ambivalence about Augustus and contemporary Rome go hand in hand'164

In addition to the scholarly views above, I am putting forward that when Vergil describes Aeneas using loaded expressions such as rex Aeneas or pius Aeneas, he is in fact also referring functionally to Augustus. This matches the Roman belief that excellent traits run in aristocratic families and that, consequently, Aeneas' positive qualities of character return in Augustus (Powell, 2004, 162). Cairns (1989, 3-4) also refers to the many instances in the Aeneid where the word rex or related words are used. He compares this with the Iliad and the Odyssey and concludes that Vergil

164 Tarrant (2000, 178-179; 2012, 24-30). Thomas (1988b, 261), stated: "While we can never quite say, without reducing the Aeneid to something less than what it is, that Aeneas is Augustus, at the same time to deny a general correspondence and relationship between the two would be to suggest that Virgil was isolated from the great events through which he lived - an isolation which would be at odds with his attitude in the Eclogues and Georgics, and which would in any case be intrinsically unlikely." See also Binder, 1971. 
uses the term far more often ${ }^{165}$. The character most frequently described as king is Aeneas, which is a clear indirect link between Aeneas and Augustus. Cairns $(1989,4)$ formulates this as: "Of course caution must be exercised in applying things said about Aeneas to Augustus, and the pair are to be seen as analogues rather than equated. But any repeated attribute of Aeneas must to some extent have reflected on Augustus.” The same holds for pietas. Although the number of times that the words pius Aeneas are used has not been counted as in the case of the word rex, it has been mentioned that pietas and Aeneas are much connected. Vergil never applied the notion pietas (or pius) in the direct sense to Augustus: the connection is by implication, as for instance in A.1.294-296, where Iuppiter speaks of the end of furor impius when Augustus closes the gates of war (Powell, 2004, 157-159, esp. at 158, and 143-149). Augustus saw pietas as an important value and thus I see the use of the word in the Aeneid as another significant reference to the princeps and his ideals.

Indeed, I concur with Tarrant's $(2012,24)$ point that the "connections between the two [Augustus and Aeneas] are so strong that the view taken of one must inevitably colour one's view of the other." I argue that this is precisely what Vergil wanted to achieve by applying the functional model. The ambivalence in the case of both Dido and Aeneas lies in the poet's use of two models at the same time, a literary and a functional. However, he did this for different purposes: the literary model had a literary objective, the functional model had a political objective. Although I argue that Augustus is the functional model for Aeneas, there are passages in the epic which seem to contradict this view, for example A.8.671-728, which I discussed above. In this and other passages the historic Augustus Caesar has his very own role (Actium, triple triumph). This is similar to the manner in which Cleopatra features in the Aeneid: both as Dido modelled on Cleopatra and in her own right as Cleopatra, queen of Egypt. However, there is no contradiction when Vergil presents the models in their own historic reality. On the contrary, Vergil reinforces the reader's association between the models (Augustus, Cleopatra) and the modelled (Aeneas, Dido): a main function of the functional model is indeed to evoke an allusion to contemporary persons or events, and readers would experience the poet's presentation of historic Augustus and Cleopatra as an affirmation of their association.

\subsection{Summary}

In the Aeneid, Vergil refers several times to both Augustus and Cleopatra. These references are either direct, or indirect, or achieved through the use of functional models for Aeneas and Dido. Vergil uses Cleopatra extensively as a functional model for Dido. Although he uses Augustus in some cases as a functional model for Aeneas,

165 Iliad 287 times, Odyssey 194 times and Aeneid 334 times. 
this is not as frequent and comprehensive as the poet's use of Cleopatra as a model for Dido.

The political themes which emerge most strongly in the Aeneid are in general the same as those in the Eclogues and the Georgics. For instance, the sufferings caused by the civil war and the violation of the countryside (A.10.310-311, 12.766-771), Vergil's expectations of better times under Augustus' reign (A.6.792-794, 8.626-731), and his view that a stable one-man rule is needed to establish peace and order (A.6.860886, 8.319-322). The epic also has several passages that are very critical of Augustus. For example, in A.6.847-853 Vergil is critical of the high price to be paid for imperial success; in A.11.100-105 and A.11.372-373 he condemns the violence of the civil war; in A.12.945-952 he is critical of Augustus' use of violence (symbolized by the brutal killing of Turnus); and in A.12.35-36 he is critical of the many victims in the civil war (Latinus' speech about the many victims in the war with Aeneas). Contrary to many scholars, I conclude that Vergil held Cleopatra in high regard. 